\title{
Regulation of retinal axon growth by secreted Vax1 homeodomain protein
}

\author{
Namsuk Kim¹, Kwang Wook Min'1, Kyung Hwa Kang², Eun Jung Lee', \\ Hyoung-Tai Kim¹, Kyunghwan Moon ${ }^{1}$, Jiheon Choi', Dai Le', Sang-Hee Lee1, \\ Jin Woo Kim ${ }^{1,2 *}$ \\ ${ }^{1}$ Department of Biological Sciences, Korea Advanced Institute of Science and \\ Technology, Daejeon, Republic of Korea; ${ }^{2}$ KAIST Institute of BioCentury, Korea \\ Advanced Institute of Science and Technology, Daejeon, Republic of Korea
}

\begin{abstract}
Retinal ganglion cell (RGC) axons of binocular animals cross the midline at the optic chiasm (OC) to grow toward their synaptic targets in the contralateral brain. Ventral anterior homeobox 1 (Vax1) plays an essential role in the development of the OC by regulating RGC axon growth in a non-cell autonomous manner. In this study, we identify an unexpected function of Vax 1 that is secreted from ventral hypothalamic cells and diffuses to RGC axons, where it promotes axonal growth independent of its transcription factor activity. We demonstrate that Vax 1 binds to extracellular sugar groups of the heparan sulfate proteoglycans (HSPGs) located in RGC axons. Both Vax1 binding to HSPGs and subsequent penetration into the axoplasm, where Vax1 activates local protein synthesis, are required for RGC axonal growth. Together, our findings demonstrate that Vax1 possesses a novel RGC axon growth factor activity that is critical for the development of the mammalian binocular visual system.
\end{abstract}

DOI: 10.7554/eLife.02671.001

*For correspondence: jinwookim@kaist.ac.kr

Competing interests: The authors declare that no competing interests exist.

Funding: See page 18

Received: 28 February 2014 Accepted: 03 September 2014 Published: 08 September 2014

Reviewing editor: Marianne E Bronner, California Institute of Technology, United States

(c) Copyright Kim et al. This article is distributed under the terms of the Creative Commons Attribution License, which permits unrestricted use and redistribution provided that the original author and source are credited.

\section{Introduction}

Development of the mammalian binocular visual system requires topographic synaptic connections of retinal ganglion cell (RGC) axons to neurons on the lateral geniculate nucleus and superior colliculus of the brain (Lemke and Reber, 2005). To access their synaptic targets, RGC axons exit from the retina and grow in selective directions by recognizing guidance cues expressed in optic pathway structures, including the optic disc (OD), optic stalk (OS), optic chiasm (OC), and optic tract (OT) (Petros et al., 2008). RGC axon guidance cues include cell surface ligands such as semaphorins in the $O S$ and ephrinB2 in the OC, and soluble factors such as netrin-1 in the OD and Slit1 in areas surrounding the OC (Erskine and Herrera, 2007). Ultimately, only about 3\% of mouse RGC axons, which originate from the ventral and temporal part of the retina, are linked to targets on the same side of the brain, whereas a majority of RGC axons are connected to those on the opposite side after crossing the midline at the $\mathrm{OC}$, located at the ventral-medial hypothalamic ( $\mathrm{vHT}$ ) area.

Subsets of vHT cells therefore express molecules that determine the directionalities of RGC axons at the OC. It has been shown that vHT radial glial cells express ephrinB2, which binds to EphB1 receptors expressed in ventral-temporal RGC axons and repels the axons toward the ipsilateral optic tract (Nakagawa et al., 2000; Williams et al., 2003). In addition, vascular endothelial growth factor 164 (VEGF164), an isoform of the vascular endothelial growth factor VEGF-A (Soker et al., 1996), and neuronal cell adhesion molecule (NrCAM) expressed in the $\mathrm{vHT}$ have been suggested to support the growth of RGC axons across the vHT midline by binding to neuropilin-1 and plexin-A1, respectively (Williams et al., 2006; Erskine et al., 2011; Kuwajima et al., 2012). To receive the directional guidance of these molecules at the vHT, RGC axons must pass through the ventral-lateral diencephalic area, where repulsive guidance cues, such as Slit and semaphorins, are expressed at high levels (Erskine et al., 2000; Plump et al., 2002). However, the molecules that support RGC axon growth toward the vHT midline are still unknown. 
eLife digest We see the world around us when light bounces off of objects and hits the retina at the back of our eyes. This triggers electrical signals in neurons called retinal ganglion cells (RGCs), which have long structures called axons that extend out from the retina and into the parts of the brain where the signals are interpreted. As the axons grow, various 'guidance' molecules direct the axons to the correct part of the brain.

One molecule that is important for the growth of retinal ganglion cells' axons is a protein called Vax1. This protein is a transcription factor and binds to DNA to control how and when the molecular templates used to make proteins are made-a process called transcription. Vax 1 is not produced in retinal ganglion cells, but it does control the extension of these cells' axons into part of the brain called the ventral hypothalamus. In this study, the axons cross to the other side of the brain by forming a structure called optic chiasm. Humans and mice lacking Vax1 are unable to develop the optic chiasm, and the axons of their retinal ganglion cells do not reach their targets in the brain. These defects were thought to occur because the guidance molecules whose transcription is normally controlled by Vax1 were not produced in the correct amounts when Vax1 is absent.

Kim et al. now challenge this view by creating a mutant version of Vax 1 that cannot bind to DNA or regulate the transcription of other proteins. Retinal ganglion cell axons could still grow correctly when they were put close to cells expressing this version of the Vax1 protein. This contradicts a hypothesis that Vax1 supports axonal growth by transcribing guidance molecules. Kim et al. followed up these results by examining developing mice and reached the unexpected conclusion that Vax 1 is secreted from cells in the ventral hypothalamus and binds to a type of sugar molecule found on the surface of the axons. Once bound, Vax1 can enter the axons where it appears to stimulate the production of proteins inside axons, which helps the axons to grow.

These findings reveal unconventional functions for Vax1 that occur in addition to its role as a transcription factor. Vax1 is known to regulate the development of several structures in the brain, so the work of Kim et al. also raises new questions about how Vax1 controls these processes.

DOI: 10.7554/eLife.02671.002

Ventral anterior homeobox 1 (Vax1) is a homeodomain transcription factor expressed in various ventral-medial forebrain-derived structures, including the medial and lateral geniculate eminences, the ventral septum, the anterior entopeduncular area, the preoptic area, the $\mathrm{vHT}$, and the OS (Hallonet et al., 1998; Bertuzzi et al., 1999). Genetic inactivation of Vax1 in humans and mice causes agenesis of multiple midline structures of the brain, including the anterior commissure, the corpus callosum, and the OC, in addition to the coloboma of the eye (Bertuzzi et al., 1999; Hallonet et al., 1999; Slavotinek et al., 2012). RGC axons in Vax1-deficient mice can grow through the OS but cannot access the vHT area and fail to form an OC. Vax 1 is not expressed in RGCs despite its critical roles in growth and fasciculation of RGC axons (Bertuzzi et al., 1999; Mui et alo, 2005). Therefore, it has been suggested that defects in OC formation in Vax1-deficient mouse RGCs might be caused by the loss or gain of axon guidance cues that are potential transcription targets of Vax1 in vHT cells.

Contrary to expectation, we here found that Vax1 promoted RGC axon growth in a transcriptionindependent manner. Moreover, Vax 1 is secreted from vHT cells and binds and enters RGC axons to stimulate axonal growth. This unexpected trafficking of Vax1 to RGC axons was mediated by heparan sulfate proteoglycans (HSPGs), such as syndecan and glypican, expressed in RGC axons. However, Vax1 binding to HSPGs was not sufficient to trigger RGC axon growth; penetration into the RGC axoplasm and subsequent stimulation of local protein synthesis were also necessary. Taken together, our findings reveal an unconventional function of Vax 1 as an RGC axon growth factor that enables RGC axons to grow toward the midline during development.

\section{Results}

\section{Vax1 regulates the RGC axonal growth in a non-cell autonomous manner}

Vax 1 is expressed in cells located in optic pathway structures, such as the $\mathrm{OS}$ and $\mathrm{vHT}$, and plays an essential role in fasciculation of RGC axons and formation of the OC (Bertuzzi et al., 1999; Hallonet et alo, 1999). At the vHT of days post coitum 14.5 (E14.5) mouse embryo, Vax1 is expressed in 
Sox2 (SRY box 2)-positive neural progenitor cells (NPCs) and RC2-detectable nestin-positive radial glia (Figure $1 A, B$; top rows), which is known to provide RGC axon guidance cues (Petros et al., 2008). Although the morphology of the chiasm is abnormal in Vax1-deficient $\left(V_{a x 1^{--}}\right)$mice (Bertuzzi et alo, 1999), these OC-forming cells and several chiasm-localized cues (NrCAM and Vegfa) are still present (Figure 1A,B, bottom rows; Figure 1-figure supplement 1). However, vHT explants from Vax $1^{-1-}$ mice were unable to attract RGC axons regardless of the Vax1 gene status of co-cultured retinal explants, whereas wild-type (WT; Vax $\left.1^{+/+}\right) \mathrm{vHT}$ explants were able to attract $\mathrm{RGC}$ axons projected from Vax $1^{-1-}$ explants as well as WT explants (Figure $\left.1 C, D\right)$. We therefore concluded that Vax1 controls

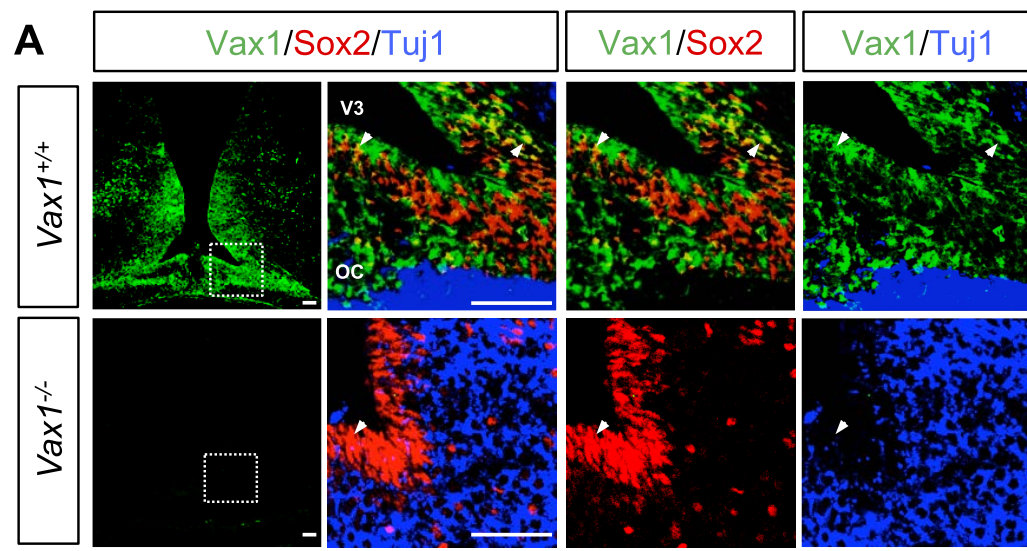

B

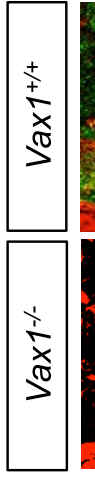

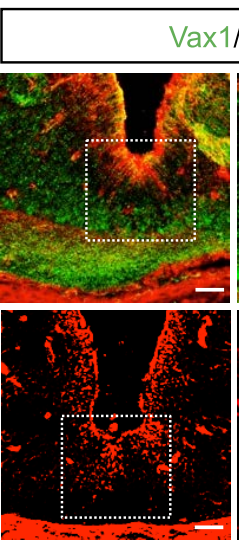

\section{1/RC2}

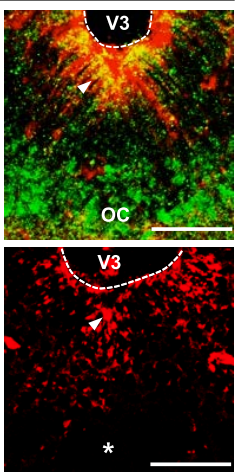

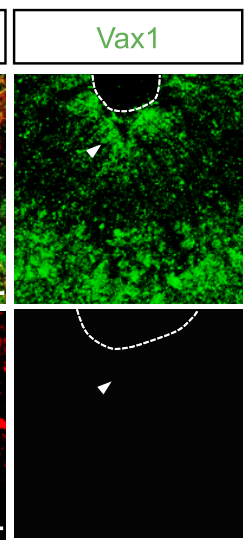

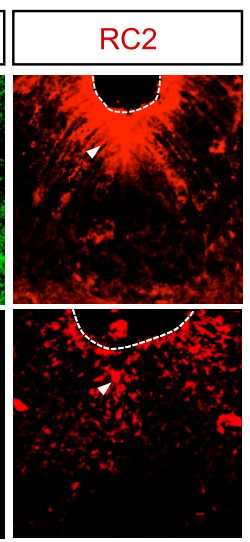

C

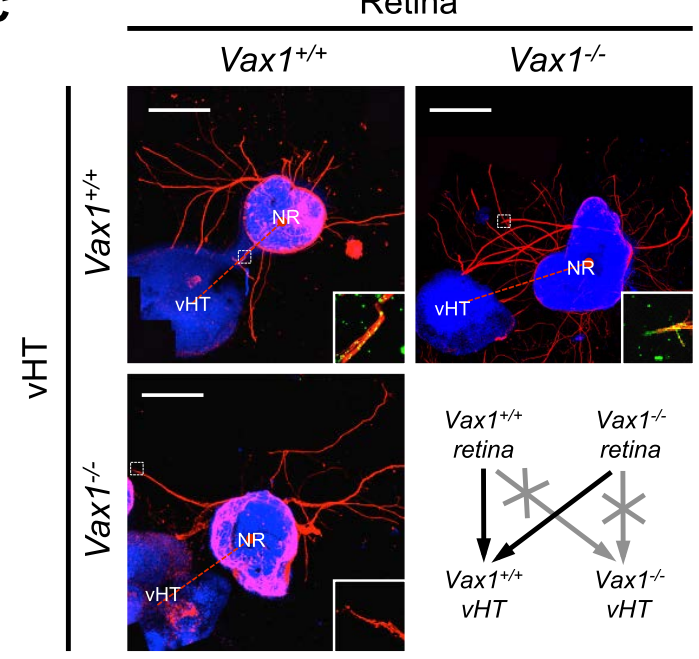

D

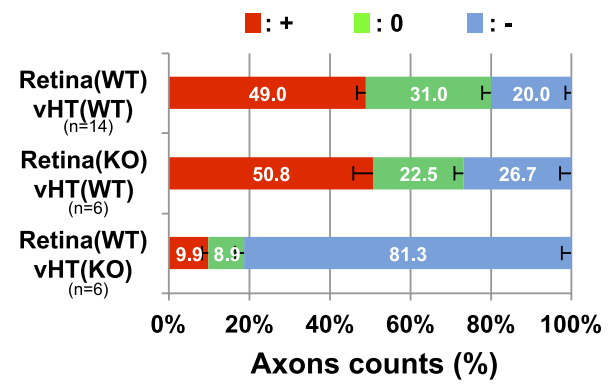

Figure 1. Vax1 regulates RGC axonal growth in a non-cell autonomous manner. (A) Cells expressing Vax1 (green) in brain sections (coronal; 16 4m) from E14.5 $\mathrm{Vax}^{1^{+/+}}$(top) and $\mathrm{Vax}^{1^{-/-}}$(bottom) embryos were detected by co-immunostaining for the NPC marker Sox2 (red) and post-mitotic neuronal marker tubulin- $\beta$ III (blue), detected with the Tuj1 antibody. The right-most three columns are the magnified images of dotted boxes in the left column image. The results indicate that Vax1 is expressed in a subpopulation of Sox2-positive NPCs (arrowheads) but is not detectable in Tuj1-positive neurons. (B) Vax1-expressing cells in the vHT were also compared with RC2-positive radial glia. Arrowheads indicate RC2-positive radial glial cells expressing Vax1.

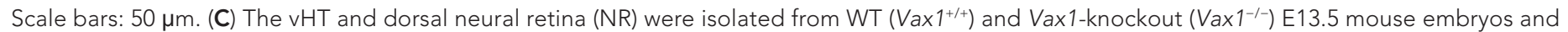
co-cultured in a combinatorial manner for $48 \mathrm{hr}$. The explants were fixed and immunostained with an anti-NF160 antibody ( $\alpha$-NF160; red); nuclei were counterstained with DAPI (blue). Dotted boxes indicate the area magnified in each inset. Red dotted lines link centers of retinal explants and vHT explants. Scale bars: $500 \mu \mathrm{m}$. (D) The angular distribution of RGC axons in images was measured by counting pixels containing immunostaining for the axon marker NF160 (axon counts), as described in 'Materials and methods', and presented graphically. +, forward direction angle segment; 0, neutral direction angle segments; -, reverse direction angle segment. The values in the bar are averages, error bars denote standard deviations (SDs), and numbers under $y$-axis labels are the numbers ( $n$ ) of explants analyzed from three independent experiments. p-values determined by the analysis of variance (ANOVA) are between 0.01 and 0.005 .

DOI: 10.7554/eLife.02671.003

The following figure supplement is available for figure 1:

Figure supplement 1. Expression of RGC axon attractive cues in Vax $1^{-1-}$ mouse $\mathrm{vHT}$. DOI: 10.7554/eLife.02671.004 
the RGC axonal growth in a non-cell autonomous manner, potentially by regulating the expression of unidentified secreted axon-guidance molecules.

\section{Vax1 is a secreted protein}

To identify Vax1-regulated secreted factors that control RGC axonal growth from co-cultured retinal explants, we overexpressed mouse Vax1 in COS7 cells. RGC axons from retinal explants grew preferentially toward co-cultured Vax1-expressing COS7 cell aggregates, whereas RGC axons projected in random directions upon co-incubation with untransfected or Vax2-overexpressing COS7 cell aggregates (Figure 2A,B). Because Vax2 shares an identical homeodomain with Vax1 (Barbieri et al., 1999), these results indicate that the RGC axon growth stimulatory activity is specific for Vax1.

We next examined whether Vax1-induced RGC axonal growth is dependent on Vax1 transcription activity by co-incubating retinal explants with COS7 cells expressing a transcriptionally inactive Vax1(R152S) mutant (Figure 2, Figure 2-figure supplement 1). This mutation was reported in a human patient who exhibited coloboma, cleft palate, and agenesis of corpus callosum (ACC), phenotypic manifestations similar to those of Vax $1^{-1-}$ mice (Slavotinek et al., 2012). Unexpectedly, we found that Vax1(R152S)-expressing COS7 cells were also able to induce RGC axonal growth as efficiently as WT Vax1-expressing COS7 cells (Figure 2A, third row, B), suggesting that Vax1 induces RGC axonal growth in a transcription-independent manner.

More strikingly, Vax1 and Vax1(R152S) proteins were not only expressed in transfected COS7 cells, they were also detectable in neurofilament $160 \mathrm{kDa}$ (NF160)-positive RGC axons projecting from co-cultured retinal explants (Figure 2A, right two columns). These axonal Vax1-immunostaining signals were remarkably decreased in the presence of a rabbit anti-Vax1 polyclonal antibody ( $\alpha-V a x 1)$ that sequesters Vax1 in the growth medium (Figure 2-figure supplement 2). Furthermore, Vax1 and Vax1(R152S) proteins were found in the growth medium of transfected COS7 cells, whereas Vax2 protein was not (Figure 2C). Since the viability of the transfected COS7 cells were not different from each other (data not shown), these results suggest that Vax1 proteins in the growth medium and co-cultured RGC axons did not originate from dead cells. Similar to overexpressed Vax1 in COS7 cells, endogenous Vax1 expressed in vHT explants was detectable in the growth medium (Figure 2D). Furthermore, Vax1 protein was also identified in the cerebral spinal fluid (CSF) of E14.5 mouse embryos (Figure 2E), suggesting that Vax1 is secreted in vivo as well as in vitro.

\section{Vax1 has retinal axon growth factor activity}

We further tested whether secreted Vax1 is capable of directly binding to RGC axons and regulating axonal growth using purified recombinant Vax1 protein. Time-lapse recordings of RGC axons revealed that fluorescein isothiocyanate (FITC)-labeled, His-tagged Vax1 (Vax1-His) protein added to the growth medium of retinal explants accumulated in RGC axons and exerted strong growth stimulatory effects on them (Figure 3A,B; Videos 1-3; Figure 3-figure supplement 1). The axon growth stimulating effects of Vax1-His were applied equally to retinal quadrants (Figure 3-figure supplement 2), implicating Vax1 is not a region-specific axon growth factor. The transcriptionally inactive Vax1(R152S)-His mutant protein was also detectable in RGC axons and stimulated axonal growth as efficiently as WT Vax1-His (Figure 3C,D), suggesting that extracellular Vax1 moves to RGC axons and induces axonal growth in transcription-independent manner. Despite that Vax2 is not secreted (Figure 2C), the ability of recombinant Vax2-His to be internalized and induce RGC axonal growth is almost equivalent to that of Vax1 (Figure 3-figure supplement 3), implicating that internalization but not secretion is a conserved characteristic of VAX transcription factors.

\section{In vivo evidence for intercellular transfer of Vax1}

We next sought evidence for the transfer of Vax1 to RGC axons in vivo. As reported previously (Hallonet et alı, 1998; Bertuzzi et al., 1999), Vax1 mRNA is expressed in RGC axon-associated structures, including the $\mathrm{OD}$, the $\mathrm{OS}$, and the $\mathrm{vHT}$, but not the retina, of E14.5 mice (Figure 4A, Figure 4-figure supplement 1A). However, an examination of Vax1 protein distribution in E14.5 Vax 1lacz/+ heterozygous mouse embryos showed that Vax1 was detectable in the retina as well as the OS and OD (Figure 4B, top row). In these mice, $\beta$-galactosidase ( $\beta$-gal) is expressed from a lac $Z$ gene replacing one Vax1 gene locus while Vax1 is expressed from the other intact Vax1 gene locus (Hallonet et al., 1999); therefore, $\beta$-gal should be expressed in cells expressing Vax1. However, we found that RGCs in Vax $1^{\text {laczl+ }}$ mice did not express $\beta$-gal but did express Vax 1 , this contrasts with OS APCs which co-expressed Vax 1 and $\beta$-gal (Figure 4B, top row). Vax1-immunostaining signals were completely absent in RGCs as well as 
A
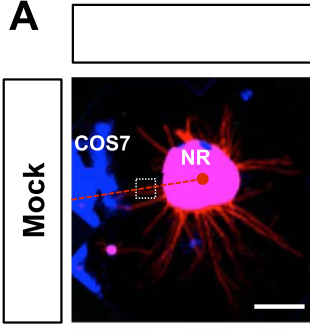

Myc/NF160/DAPI
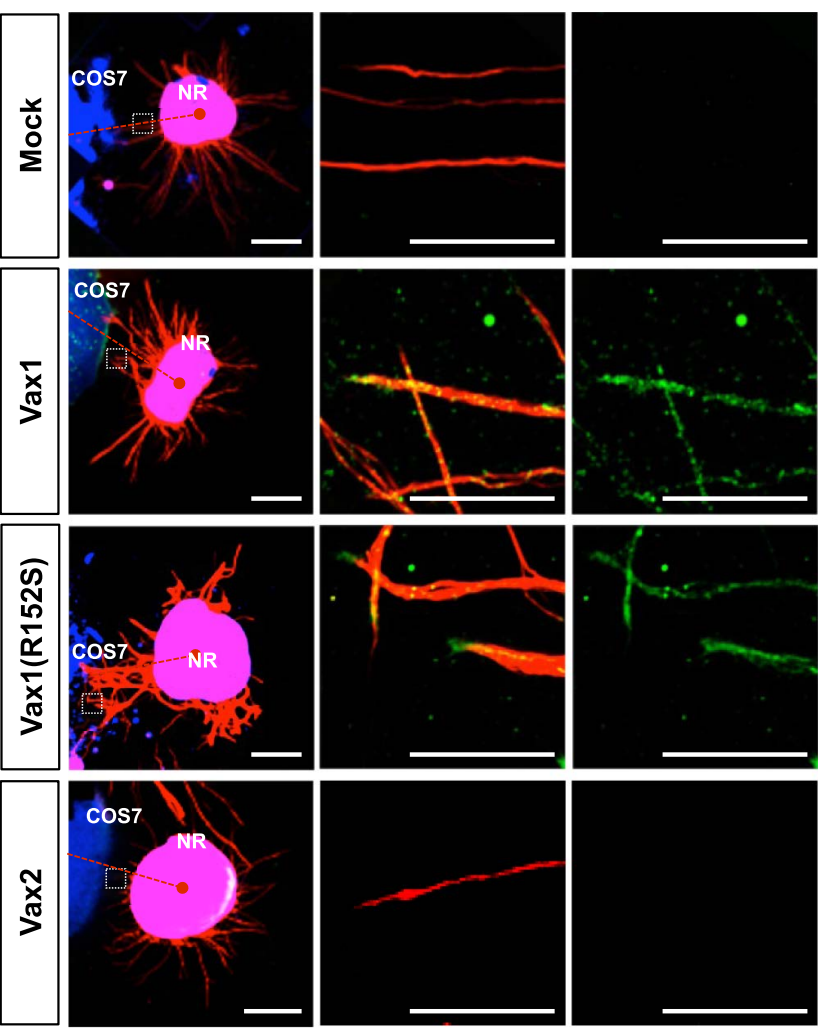

D

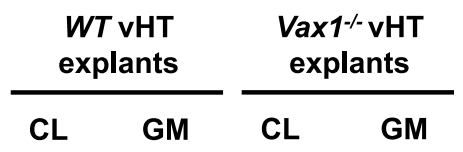

\section{WB: $\alpha-\operatorname{Vax} 1$}

WB: $\alpha$-Tubulin

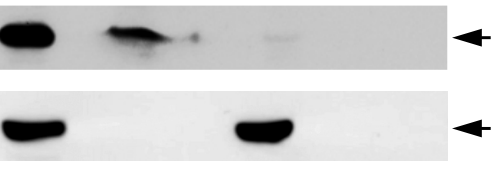

B
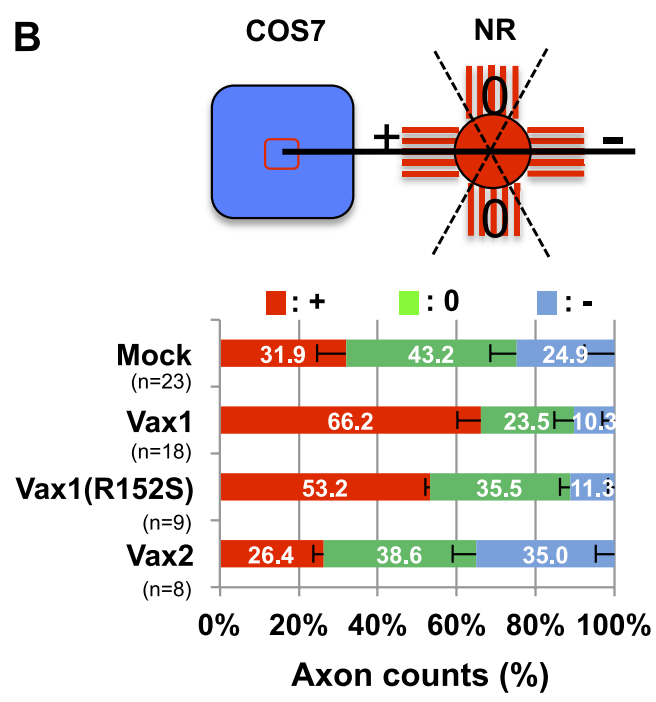

C

E

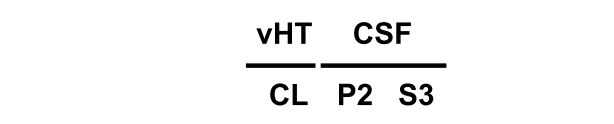

WB: $\alpha-\operatorname{Vax} 1$

WB: $\alpha-$ Tubulin
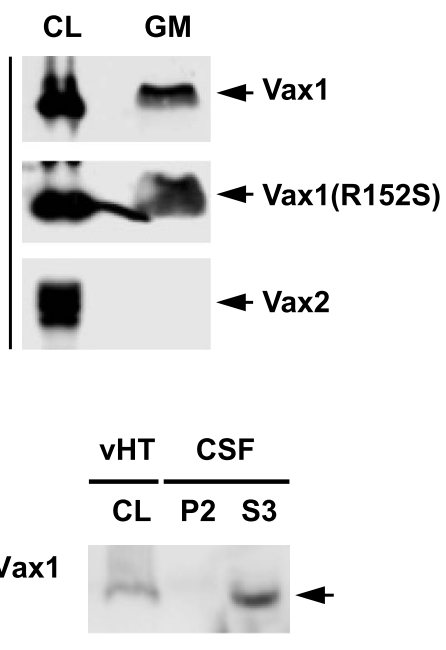

\section{.}

Figure 2. Vax1 homeodomain protein is a secreted protein. (A) COS7 cells overexpressing Myc-tagged mouse Vax1, Vax1(R152S), or Vax2 were co-cultured with E13.5 mouse retinal explants (NR) for $48 \mathrm{hr}$. The explants were then stained with a rabbit anti-Myc antibody (green) and a mouse anti-NF160 antibody (red). Nuclei of explant cells were counterstained with DAPI (blue). Dotted red lines indicate the connections between the centers of two explants. Scale bars: $500 \mu \mathrm{m}$ (left column) and $100 \mu \mathrm{m}$ (magnified immunostained images in two right-hand columns). (B) The angular distribution of RGC axons was measured as described in Figure 1D. The values in the bar are averages and error bars denote SDs. Numbers under $y$-axis labels are the number of explants analyzed from three independent experiments. p-values are between 0.01 and 0.005 (ANOVA). (C) Growth medium from COS7 cells overexpressing Myc-Vax1, Myc-Vax1(R152S), or Myc-Vax2 was collected, and the presence of Vax protein in the growth medium (GM) was detected by Western blotting (WB) with an anti-Myc antibody. The relative amounts of secreted protein were also measured by analyzing the level of proteins in the COS7 cell lysates (CL; $5 \%$ of total). (D) $\mathrm{vHTs}$ isolated from WT and Vax1 ${ }^{-1-} \mathrm{E} 13.5$ mouse embryos were cultured for $24 \mathrm{hr}$, after which GM was collected for detection of secreted Vax1 protein by Western blotting. CL, cell lysates of vHT explants ( $5 \%$ of total). (E) Cerebrospinal fluid (CSF) from E14.5 mouse embryos ( $n=20$ ) was collected, a supernatant fraction (S3) was separated from cell debris (P2) by step-wise centrifugation (see 'Materials and methods' for details), and the presence of Vax1 protein was examined by Western blotting. The presence of $\beta$-tubulin, a cytoplasmic protein, was also examined in GM and CSF fractions to check for the possible non-specific release of intracellular proteins from dead cells. CL, E14.5 vHT cell lysates (2\% of total lysates from one embryonic vHT). DOI: 10.7554/eLife.02671.005

The following figure supplements are available for figure 2:

Figure supplement 1. Relative transcriptional activities of Vax1 mutants used in this study. DOI: 10.7554/eLife.02671.006

Figure supplement 2. Interference of Vax1 intercellular transfer by sequestering extracellular Vax1. DOI: 10.7554/eLife.02671.007 
$\mathbf{A}$
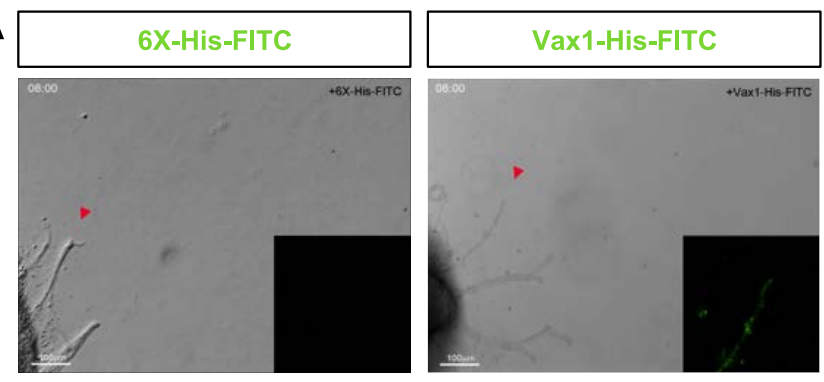

C
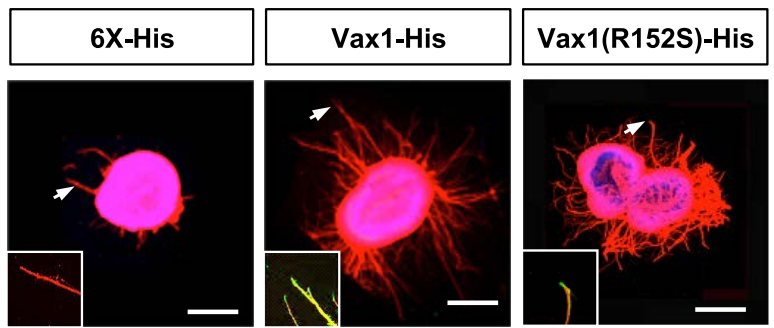

B
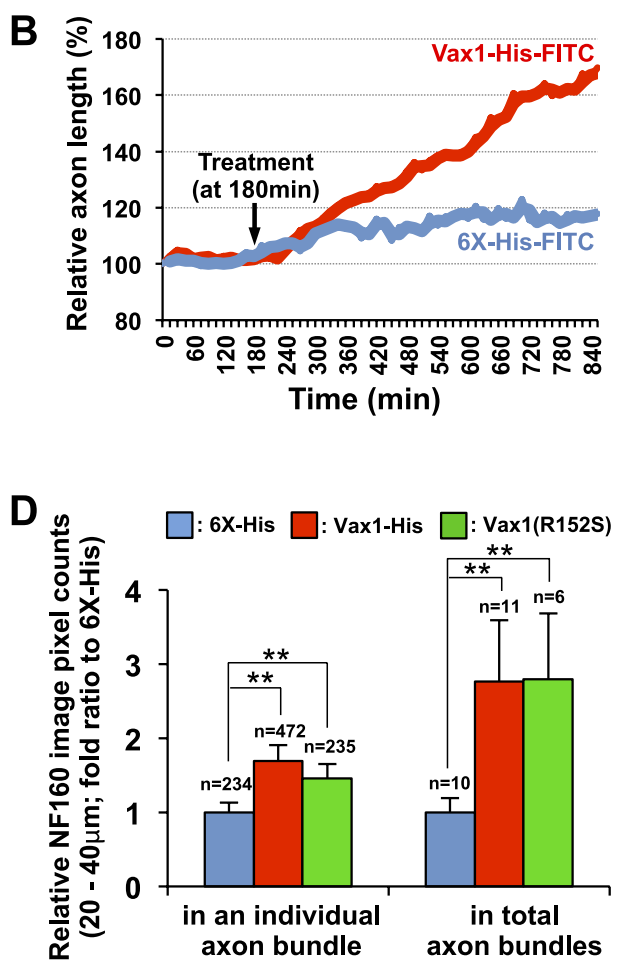

Figure 3. Vax1 protein is a retinal axon growth factor. (A) E13.5 mouse retinal explants were cultured for $24 \mathrm{hr}$ and then treated with $6 \mathrm{X}$-His-FITC peptide $(100 \mathrm{ng} / \mathrm{ml})$ or recombinant Vax1-His-FITC protein $(500 \mathrm{ng} / \mathrm{ml})$ for an additional $24 \mathrm{hr}$. Images of RGC axons were taken every $15 \mathrm{~min}$ for $16 \mathrm{hr}$ before immunostaining with anti-Vax1 and anti-His antibodies (Videos 1 and 2; Figure 3-figure supplement 1). The accumulation of 6X-His-FITC and Vax1-His-FITC in growing RGC axons was also visualized by detecting FITC fluorescence signals (inset images). Red arrowheads indicate the area magnified in each inset. (B) The changes in RGC axonal length during the recording were plotted after adjusting the initial length to 100\%. (C) Retinal explants treated with 6 X-His $(25 \mathrm{ng} / \mathrm{ml})$, Vax1-His (100 ng/ml), or Vax1(R152S)-His (100 ng/ml) for 24 hr were stained with rabbit anti-Vax1 (green) and mouse anti-NF160 (red) antibodies to visualize Vax1 protein in RGC axons. Arrowheads indicate the area magnified in each inset. Scale bars: 500 um. (D) Relative numbers of axon bundles projecting from retinal explants were indirectly measured by counting the pixels containing NF160 immunofluorescence in RGC axons between 20 and $40 \mu \mathrm{m}$ from the rim of the explants (total axon bundle). The relative thickness of individual axon bundles was also measured by comparing the total pixel counts of NF160 in the 20-40- $\mu \mathrm{m}$ area (individual axon bundle). The values in the graph are averages expressed relative to those of 6 X-His peptide-treated samples, presented as 1; error bars denote SDs (** $p<0.001$; ANOVA). The scores on top of the graph columns are the number of axons (individual axon bundle) and the number of explants (total axon bundle) analyzed, respectively. Results were obtained from three independent experiments. The number of explants analyzed: for 6 X-His, $n=10 ;$ Vax1-His, $n=11$; Vax1(R152S)-His, $n=6$. (already shown in total axon bundle). DOI: 10.7554/eLife.02671.008

The following figure supplements are available for figure 3:

Figure supplement 1. Penetration of exogenous Vax1 protein into RGC axons.

DOI: 10.7554/eLife.02671.009

Figure supplement 2. Region non-selective stimulation of retinal axonal growth by recombinant Vax1.

DOI: 10.7554/eLife.02671.010

Figure supplement 3. Recombinant Vax2 is capable for inducing RGC axon growth in vitro.

DOI: 10.7554/eLife.02671.011

ß-gal-positive OS APCs from homozygous lacZ knock-in (Vax1lacz/lacz) Vax1laczlacz littermates, suggesting that Vax1 immunostaining signals in the Vax1lacz/+ mouse RGC were specific (Figure 4B, bottom row). Collectively, these data demonstrate that Vax1 protein in RGCs might originate from the neighboring Vax1/ß-gal double-positive APCs in the OS or NPCs and radial glia in the vHT (Figure 4B, Figure 4figure supplement $1 B)$.

Vax1 protein in OS APCs was present mainly in nuclei, whereas a majority of Vax1 protein in $\beta$-galnegative RGCs was non-nuclear (Figure 4B, i and ii). Furthermore, Vax1 co-localized with NF160 in E14.5 WT mouse RGC axons but was lost in Vax1laczlacz mouse RGC axons (Figure 4C). These Vax1 localization patterns in the OS APCs and RGCs were further confirmed by immuno-transmission electron microscopy. 


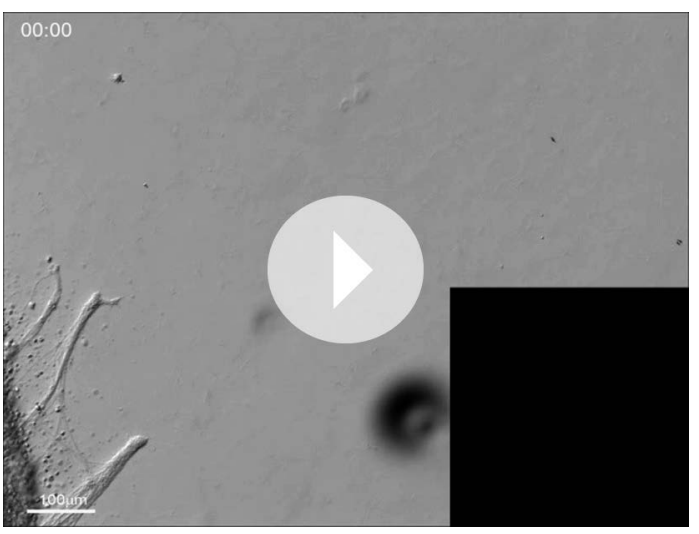

Video 1. Time-lapse video of E13.5 mouse retinal explants cultured in the presence of 6X-His-FITC peptides $(100 \mathrm{ng} / \mathrm{ml})$ as described in 'Materials and methods'. DOI: 10.7554/eLife.02671.012

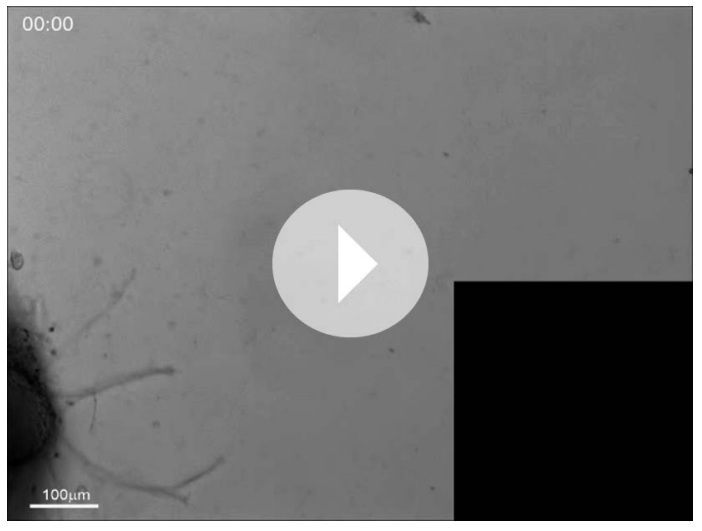

Video 2. Time-lapse video of E13.5 mouse retinal explants cultured in the presence of Vax1-His-FITC proteins $(500 \mathrm{ng} / \mathrm{ml})$ as described in 'Materials and methods'. DOI: 10.7554/eLife.02671.013

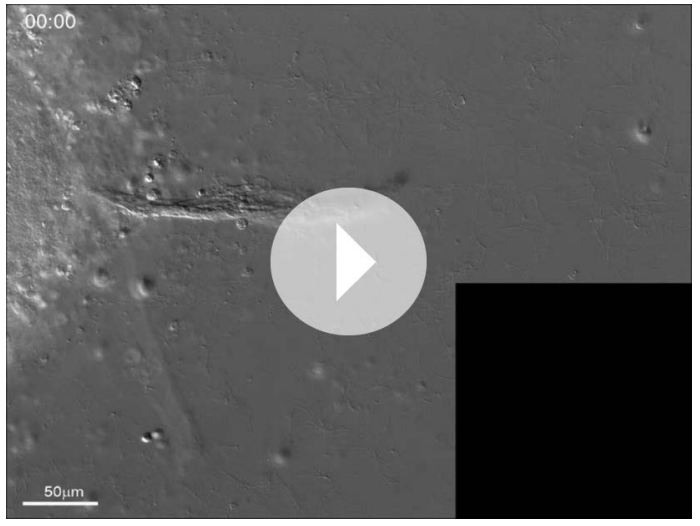

Video 3. Time-lapse video of E13.5 mouse retinal explants cultured in the presence of $6 \mathrm{X}$-His-FITC peptides (500 ng/ml) as described in 'Materials and methods'. DOI: 10.7554/eLife.02671.028
Vax1 protein was highly enriched at the extracellular part of the RGC membrane and was also detected in the cytoplasm and intracellular vesicles (Figure 4D, top row; Figure 4-figure supplement 2). Vax1 protein in OS APCs was not only enriched in nuclei but was also detectable in cytoplasmic membrane structures (Figure 4D, bottom row). These results therefore suggest that OS- and/or vHT-secreted Vax1 might enter RGCs after docking with the RGC axon membrane.

\section{Intercellular transfer of Vax 1 is necessary for RGC axonal growth}

To investigate whether the secreted Vax 1 is necessary for the growth of RGC axons toward vHT explants, we sequestered extracellular Vax 1 using $\alpha-V a x 1$. $\alpha$-Vax1 not only interfered with the transfer of Vax1 from vHT cells to RGC axons, it also antagonized RGC axonal growth toward vHT explants (Figure 5A, center). In contrast, neither rb-lgG (pre-immune rabbit lgG) nor $\alpha$-Vax2 influenced Vax 1 transfer into RGC axons or RGC axonal growth toward vHT explants (Figure 5A, left and right). $\alpha$-Vax 1 treatment not only reduced the population of retinal axons growing toward the $\mathrm{vHT}$ (Figure 5B), it also decreased the total number of retinal axons growing from the explants (Figure 5C), suggesting an axogenic activity as well as an axon growth-stimulating activity of extracellular Vax1.

The roles of extracellular Vax1 in RGC axon growth were also investigated in vivo. Collagen gels releasing rb-lgG or $\alpha-V a x 1$ were implanted in the third ventricle of E13.5 mouse embryonic brain slabs to sequester extracellular Vax 1 in the vHT area (Figure 5D, diagram on top panel). Mouse embryos implanted with $\alpha$-Vax1-releasing gels showed a remarkable reduction in RGC axons accessing the midline compared with embryos implanted with rb-lgG-releasing gels (Figure 5D). In $\alpha$-Vax1-implanted mouse embryos, a significant number of RGC axons showed reduced Vax 1 immunoreactivity and stopped at the lateral wall of the ventral diencephalon, properties similar to those observed in Vax $1^{-/-}$mice (Bertuzzi et al., 1999) (Figure 5D, bottom row). Taken together, these results suggest that extracellular Vax1 is necessary for RGC axonal growth to the ventral midline.

\section{Heparan sulfate proteoglycan regulates Vax1 intercellular transfer}

Intercellular transfer has also been reported for other homeodomain transcription factors, such as engrailed-2 (En2) and orthodenticle homeobox 

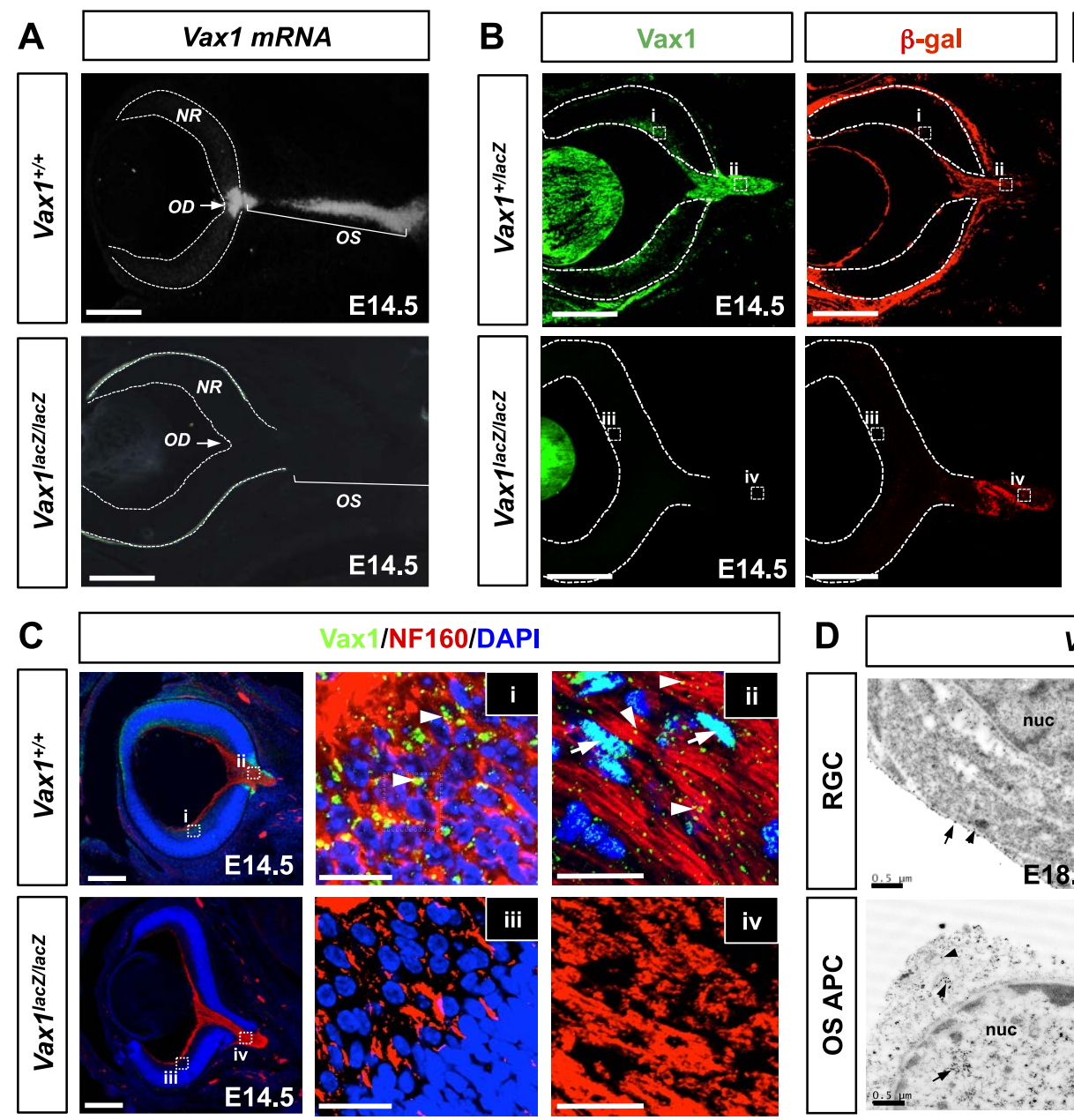
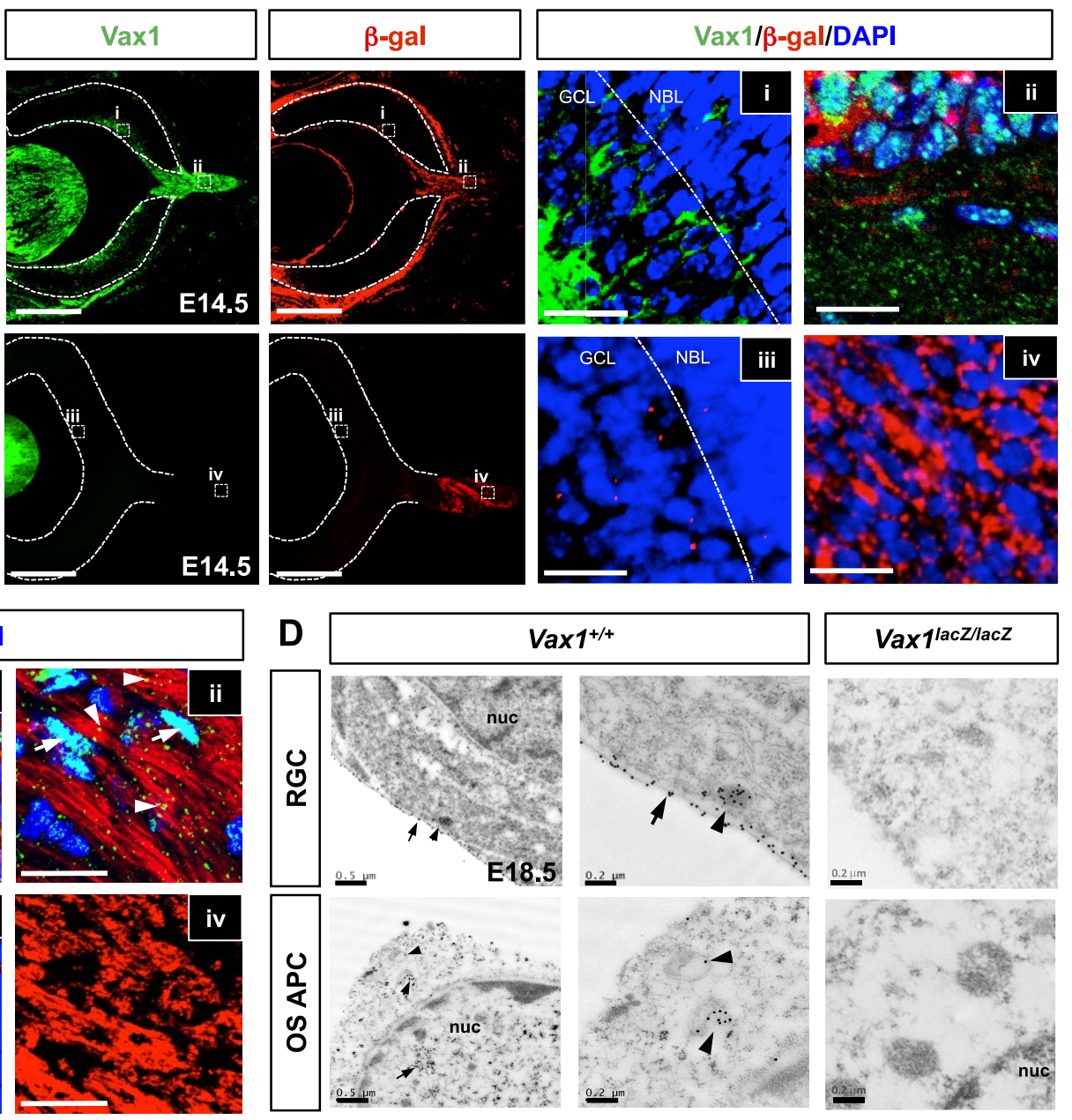

Figure 4. Mouse RGC axons import Vax1 protein. (A) Vax1 mRNA expression in E14.5 WT $\left(\right.$ Vax $\left.1^{+/+}\right)$mouse retinas was examined by in situ RNA hybridization using a [33P]-CTP-labeled antisense Vax1 probe, as described elsewhere (Mui et al., 2005). Vax1 transcripts were detected in the OS and OD, but not in the neural retina (NR). This in situ hybridization signal was absent in Vax1laczlacz homozygous knock-in mouse eyes (bottom). (B) The distribution of Vax1 protein in the NR (i and iii) and OS (ii and iv) of E14.5 Vax1lacz/+ and Vax1laczlacz embryos was compared with that of $\beta$-gal expressed from the lacZ gene at the Vax1 locus by co-staining with rabbit anti-Vax1 (green) and mouse anti- $\beta$-gal (red) antibodies. Vax1 protein detected in Vax1lacz/+ mouse retinal cells, where $\beta$-gal signals were absent, is presumed to originate from external sources that co-express Vax 1 and $\beta$-gal. Red dots in (iii) are non-specific background $\beta$-gal immunostaining. (C) Distribution of Vax1 in RGC axons and cell bodies was examined by co-immunostaining for Vax1 (green) and the RGC axonal marker NF160 (red). Nuclei were counterstained with DAPI (blue). Arrowheads in (ii) indicate Vax1 protein that co-localizes with NF160, whereas arrows point to Vax1 in APC nuclei. Vax1 immunostaining signals were completely absent in the OS and NR of Vax1laczlacz mice, whereas NF160 immunostaining was still detectable in defasciculated RGC axons (iii and iv). (D) Sections of E18.5 WT and Vax1laczlacz mouse retinas (top) and optic nerves (ON; bottom) were immunostained with rabbit anti-Vax1 antibody and gold $(25 \mathrm{~nm}$ )-labeled anti-rabbit lgG. Subcellular localization of Vax 1 proteins was then examined by electron microscopy. Arrowheads in RGC images point to Vax1 proteins in the intracellular vesicle, whereas arrows in the images indicate Vax 1 proteins bound to the extracellular surface of the RGC plasma membrane (top). Arrowheads in APC images indicate Vax1 proteins in trafficking vesicles, whereas arrows mark Vax1 proteins associated with chromatin in the nucleus (bottom). Scale bars in (A) to (C): $200 \mu \mathrm{m}$ (left column) and $20 \mu \mathrm{m}$ (right two columns). Scale bars in (D): $0.5 \mu \mathrm{m}$ (left column) and $0.2 \mu \mathrm{m}$ (right two columns).

DOI: 10.7554/eLife.02671.014

The following figure supplements are available for figure 4:

Figure supplement 1. Expression of Vax1 mRNA and protein in the vHT area.

DOI: 10.7554/eLife.02671.015

Figure supplement 2. Cytoplasmic localization of Vax1 in RGCs.

DOI: 10.7554/eLife.02671.016 
A
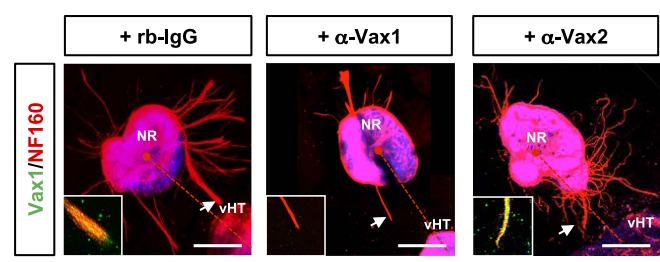

B

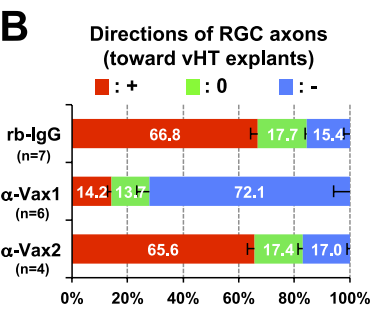

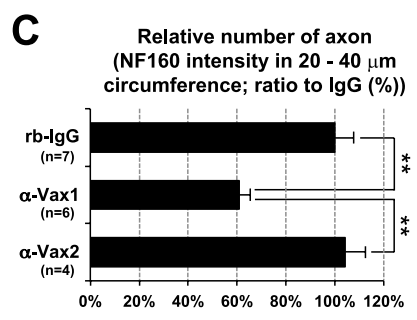

D

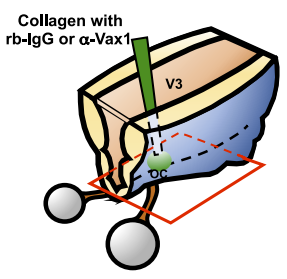

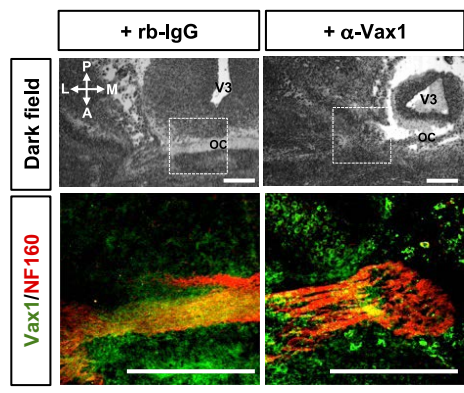

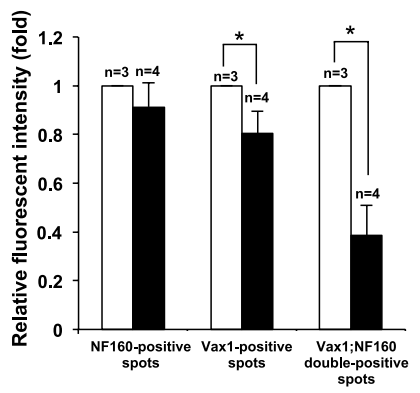

Figure 5. Secreted Vax1 protein is necessary for RGC axon growth. (A) vHTs and retinas isolated from E13.5 mouse embryos were co-cultured for 48 hr in the presence of pre-immune rabbit lgG (rb-lgG; $1 \mu \mathrm{g} / \mathrm{ml}$ ), anti-Vax1 ( $\alpha-V a x 1 ; 1 \mu \mathrm{g} / \mathrm{ml})$, or anti-Vax2 ( $\alpha$-Vax2; $1 \mu \mathrm{g} / \mathrm{ml}$ ) antibodies. Vax1 localization in RGC axons was then determined by staining explants with rabbit $\alpha$-Vax1 (green) and mouse $\alpha-N F 160$ (red). Arrowheads indicate the area magnified in each inset. Scale bars: $500 \mu \mathrm{m}$. (B) The distribution of RGC axons in each angle segment was determined as described in 'Materials and methods'. The values in the bar are averages, and error bars denote SDs. p-values are between 0.01 and 0.005 (ANOVA). (C) Total image pixel counts of NF160 immunofluorescence in a 20-40- $\mathrm{mm}$ area were compared to obtain the relative number of axons projected from each explant. Scores under $y$-axis labels of (B) and (C) are the numbers of explants analyzed in three independent experiments (** $p<0.001$; ANOVA). (D) Slabs of mouse heads including eyes, forebrain, and midbrain structures were prepared from E13.5 WT mouse embryos. The third brain ventricles of mouse-head slabs were then implanted with collagen gels containing rb-lgG $(1 \mu \mathrm{g} / \mathrm{ml})$ or $\alpha-V a x 1(1 \mu \mathrm{g} / \mathrm{ml})$ and subsequently incubated at $37^{\circ} \mathrm{C}$ in a $\mathrm{CO}_{2}$ incubator for $12 \mathrm{hr}$ (top row; see 'Materials and methods' for details). The slabs were then fixed and frozen to obtain horizontal sections (18 $\mu \mathrm{m}$ thick). The slides containing optic nerves (ON) were then further co-stained with $\alpha$-Vax1 (green) and $\alpha$-NF160 (red) and analyzed using an Olympus FV1000 confocal microscope. Images in the bottom row are magnifications of dotted boxes in the top row. Scale bars: $200 \mu \mathrm{m}$. Relative fluorescence intensities of Vax1-and/or NF160-positive immunostaining intensities in the midline area (dotted box) were measured using ImageJ software and presented graphically. White column, rb-lgG; black column, $\alpha$-Vax1. The values are relative intensities compared with rb-lgG-treated samples; error bars denote SDs and values on the top of graph columns are number of slabs analyzed ( ${ }^{\star} \mathrm{P}<0.01$; Student $t$ test). A, anterior; P, posterior; M, medial; L, lateral; ${ }^{*}$, optic chiasm; V3, third ventricle.

DOI: 10.7554/eLife.02671.017

2 (Otx2) (Joliot et al., 1998; Sugiyama et al., 2008; Spatazza et al., 2013). However, little is known about the regulatory mechanisms underlying the trafficking of homeodomain transcription factors. We therefore searched for the gene encoding proteins capable of modifying the intercellular transfer of Vax1 in Drosophila (Figure 6; screening results are unpublished). One of the genes isolated in this screen encodes the transmembrane heparan sulfate proteoglycan (HSPG) protein, syndecan (Sdc) (Spring et al., 1994). HSPGs, including Sdc2, Sdc3, and glypican 1 (Glp1), are highly expressed in mouse RGC axons and have been proposed to play critical roles in RGC axon guidance in various vertebrates (Chung et al., 2001; Inatani et al., 2003; Lee and Chien, 2004; Pratt et al., 2006). We thus focused on the potential role of HSPGs as receptors for Vax1 in RGC axons.

Vax1-GFP protein was co-expressed with DsRed protein in the A/P (anterior/posterior) boundary cells of Drosophila wing imaginal disc under the control of a Ptc-Gal4 driver. Vax1-EGFP, but not DsRed, was transferred to neighboring cells, results similar to those observed in the mammalian systems (Figure 6, top row). However, the transfer of Vax1-EGFP to neighboring wing disc cells was suppressed upon co-expression of Sdc in the A/P boundary cells (Figure 6, third row). Overexpressed dally-like protein (Dlp), a Drosophila homolog of Glp, also suppressed Vax1 transfer in the same manner as Sdc (Figure 6, bottom row), suggesting that the intercellular transfer of Vax1 in Drosophila wing imaginal disc cells is mediated by HSPGs but not specifically by Sdc. These results also imply that these overexpressed HSPGs in the A/P boundary cells captured co-expressed Vax1-EGFP protein, thereby interfering with the transfer of Vax1-EGFP to neighboring cells (Figure 6, diagram in the right column). Conversely, Vax1-EGFP proteins were transferred farther in the Sdc mutant (Sdc ${ }^{23}$ ) wing imaginal disc, where total HSPG levels were reduced owing to the loss of Sdc (Figure 6, second row). 


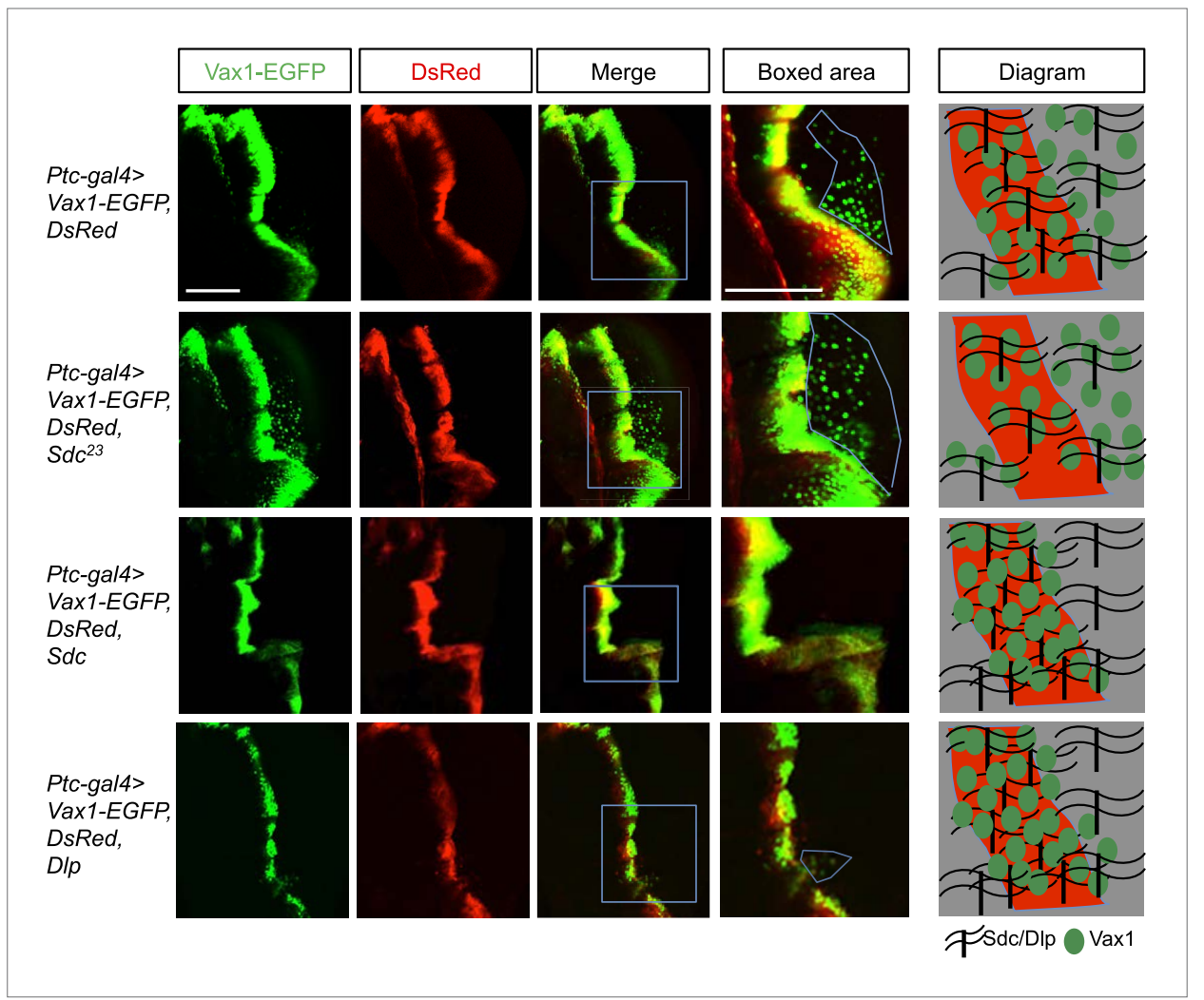

Figure 6. Regulation of intercellular Vax1 transfer by HSPGs in Drosophila wing imaginal discs. Vax1-EGFP (green) and DsRed (red) were co-expressed under the control of Ptc-Gal4 in the A/P boundary cells of Drosophila wing imaginal discs in wt (top row) and Sdc mutant (Sdc ${ }^{23}$; second row) flies. The number of cells positive for Vax1-EGFP but negative for DsRed at the posterior part of the wing disc was increased in $S d c^{23}$ flies. In contrast, the number of Vax1-EGFP-positive cells in the posterior wing disc was significantly decreased in fly embryos that co-expressed Sdc (third row) or Dlp (bottom row) together with Vax1-EGFP and DsRed. Diagrams in the right column show the distribution of Vax1-EGFP-positive cells (green) and DsRed (red) in the corresponding fly wing discs. Scale bars: $100 \mu \mathrm{m}$. DOI: 10.7554/eLife.02671.018

\section{Heparan sulfate-dependent binding of Vax1 to HSPGs is required for Vax1-induced RGC axonal growth}

HSPG-regulated Vax1 transfer was further investigated in the mammalian systems. We found that Vax1, but not Vax2, interacted with Sdc2 in E14.5 mouse optic nerves as well as with overexpressed Sdc1 and Sdc2 in human embryonic kidney (HEK) 293T cells (Figure 7A, Figure 7-figure supplement 1A,B). Sdc2-N, lacking the C-terminal cytoplasmic domain, was able to interact with Vax1, whereas Sdc2-C, which lacks the N-terminal extracellular domain, failed to interact with Vax1 (Figure 7-figure supplement 1C), suggesting that Vax1 binds to the extracellular domain of Sdc.

The extracellular domain of Sdc is attached by heparan sulfate (HS) sugars (Bishop et alo, 2007); thus, Vax1 could interact with the sugar groups as well as the protein backbone of Sdc. To determine the potential binding of Vax1 to HS side chains of Sdc2 in RGC axons, we used co-immunoprecipitation assays to test whether excess free heparin competed with HS side chains of HSPGs, including Sdc2, Sdc3, and Glp1, for binding to Vax1. Vax1 interactions with each of these HSPGs expressed in RGC axons in E14.5 optic nerves were disrupted in the presence of free heparin, whereas interactions with Pax2 (paired homeobox 2), which complexes with Vax1 in OS APCs, were not (Figure 7B). Moreover, recombinant Vax1-His specifically bound HS-sepharose resin with high affinity (Figure 7C). Collectively, these results suggest that Vax 1 preferentially binds to HS side chains of HSPG proteins expressed in RGC axons.

We also examined the influence of Vax 1 binding to HSPGs on RGC axon growth. Sdc3 was expressed in E14.5 mouse RGCs in a non-polarized manner and co-localized with Vax1 in RGC axons (Figure 7figure supplement 2). The growth stimulatory effects of Vax1 on RGC axons were abolished by the 
A

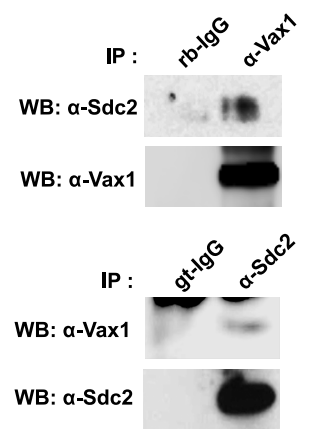

B

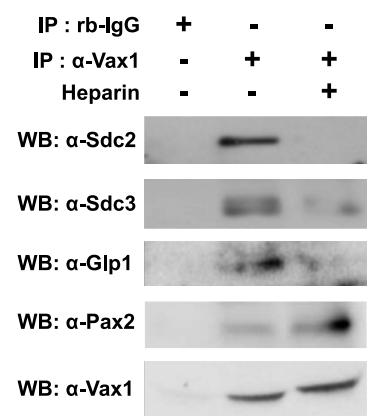

C

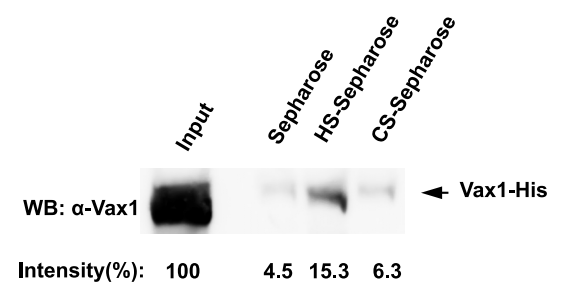

D

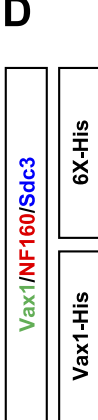

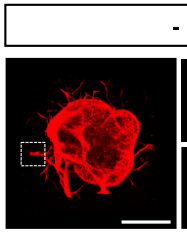

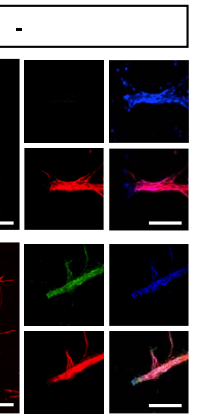

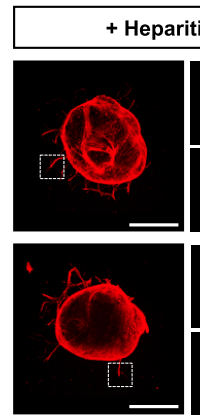

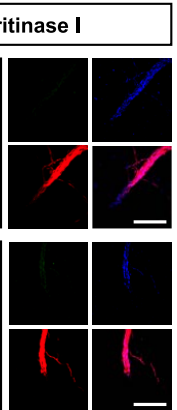

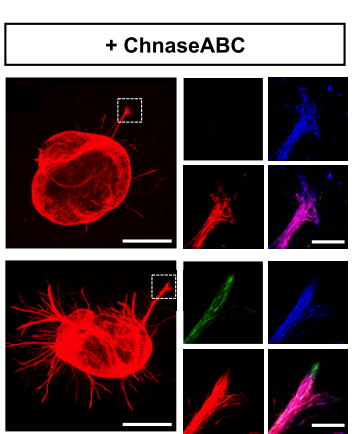

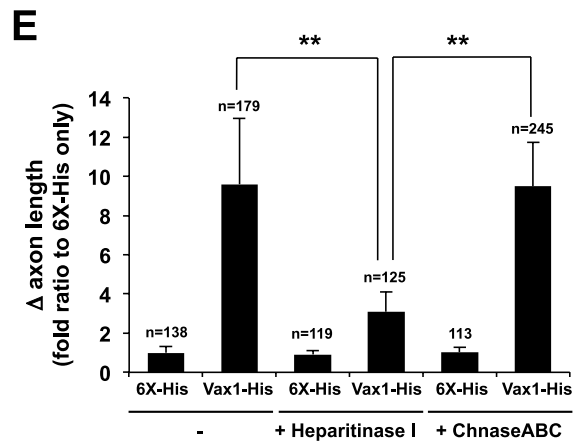

Figure 7. Vax1 binding to HSPGs is necessary for RGC axonal growth. (A) Interaction between Vax1 and Sdc2 in the E14.5 mouse optic nerve was investigated by immunoprecipitation with a rabbit anti-Vax1 (top) or goat anti-Sdc2 (bottom) antibody and subsequent Western blotting with reciprocal antibodies. The specificity of anti-Vax1 and anti-Sdc2 antibodies was confirmed by immunoprecipitation with pre-immune rabbit lgG (rb-lgG) and goat IgG (gt-lgG), respectively. (B) Immunoprecipitation of Vax1 in the E14.5 mouse OS was also performed in the presence or absence of heparin $(1 \mathrm{mg} / \mathrm{ml}$ ) to determine whether the Vax1 protein bound to HS sugar groups of Sdc2, Sdc3, and/or Glp1 HSPGs expressed in RGC axons. (C) Vax1-His protein (final concentration, $2 \mathrm{\mu g} / \mathrm{ml}$ ) was incubated at $4^{\circ} \mathrm{C}$ for $1 \mathrm{hr}$ with Sepharose $4 \mathrm{~B}$ resin (Sigma, St. Louis, MO, USA) coated with HS or CS. The resins were washed three times with PBS, and Vax1 protein bound to the resins was eluted in SDS sample buffer for subsequent SDS-PAGE on 10\% gels and Western blotting with $\alpha$-Vax1. Relative intensities of Vax1 bands in Western blot images were analyzed using ImageJ software. (D) Retinal explants were treated with heparinase I $(2.5 \mathrm{U} / \mathrm{ml})$ or ChnaseABC $(2.5 \mathrm{U} / \mathrm{ml})$ for $3 \mathrm{hr}$ and then incubated with $6 X$-His peptide $(25 \mathrm{ng} / \mathrm{ml})$ or Vax1-His recombinant protein $(100 \mathrm{ng} / \mathrm{ml})$ for an additional $24 \mathrm{hr}$. The presence of Vax1-His in RGC axons was then examined by co-immunostaining with rabbit anti-Vax1 (green), mouse anti-NF160 (red), and goat anti-Sdc3 (blue) antibodies. Dotted boxes indicate the area magnified at right. Scale bars: 500 $\mu m$. (E) The graph shows relative distances that RGC axons grew during the 24-hr incubation period. The values in the graph are averages of fold ratios compared with those of $6 \mathrm{X}$-His-treated samples, error bars denote SDs, and the scores on top of graph columns are the number of axons analyzed ( ${ }^{*} p<0.01$, ${ }^{* \star} p<0.001$; ANOVA). Results were obtained from three independent experiments. Numbers of explants analyzed: $6 X-H i s, n=6 ; V a x 1, n=7 ;$ heparinase, $\mathrm{n}=5$; chondroitinase, $\mathrm{n}=5$; Vax1+heparinase $\mathrm{I}, \mathrm{n}=6$; Vax1+ChnaseABC, $\mathrm{n}=6$.

DOI: 10.7554/eLife.02671.019

The following figure supplements are available for figure 7 :

Figure supplement 1. Molecular determination of the interaction between Vax1 and Sdc.

DOI: 10.7554/eLife.02671.020

Figure supplement 2. Co-localization of Vax1 and Sdc3 in RGC axons.

DOI: 10.7554/eLife.02671.021

treatment of retinal explants with heparinase I, which cleaves heparin and HS sugar chains, but not by incubation with chondroitinase $A B C$ (Chnase $A B C)$, which digests chondroitin sugar chains (Bishop et al., 2007; Figure 7D,E). Heparinase I treatment also decreased the immunostaining intensity of exogenously provided Vax1-His in RGC axons (Figure 7D). Neither heparinase I nor ChnaseABC influenced RGC axon growth in the absence of Vax1 (Figure 7D,E). Collectively, these results suggest that the binding of Vax1 to HSPGs is necessary for the induction of RGC axonal growth.

\section{Vax1-induced RGC growth requires local protein synthesis}

Secreted Vax1 not only bound to HSPGs at the RGC cell surface, it also moved into the RGC axoplasm by exploiting the cell-penetrating property of its homeodomain (Joliot and Prochiantz, 2004; 
Figure 4D; Figure 4-figure supplement 2). It is therefore possible that Vax1 stimulates RGC axonal growth either by acting as a ligand for HSPGs or by regulating cytoplasmic events after penetration. To answer this question, we tested the function of a Vax1(WF/SR) mutant, in which conserved Trp147 and Phe148 amino acids responsible for cell penetration were replaced with Ser167 and Arg148 (Joliot et al., 1998); this mutant lacks the ability to cross the cell membrane but remains capable of binding to Sdc2 (Figure 8-figure supplement $1 A, B$ ). We found that $\operatorname{Vax} 1(\mathrm{WF} / \mathrm{SR}$ ) barely penetrated RGC axons and induced RGC axonal growth less efficiently than WT Vax1 (Figure 8-figure supplement 1C,D). These results suggest that Vax1-induced RGC axonal growth requires cell penetration.

To determine which cytoplasmic events Vax1 might affect, we identified cytoplasmic Vax1interacting proteins by MALDI-TOF (matrix-assisted laser desorption/ionization-time of flight) mass spectrometry (Figure 8A). Interestingly, a majority of proteins isolated by Vax1-affinity purification were related to protein synthesis, including ribosomal proteins (RPs) L11, L23A, L26, S14, and S16; translation regulators, such as eukaryotic translation initiation factor (elF) $3 \mathrm{~B}$ and $3 \mathrm{C}$; and the chaperone HSPA1A (heat shock 70-kDa protein 1A). These data suggest that Vax1 might act in RGC axons by modulating protein synthesis, a mechanism similar to that by which cytoplasmic En2 controls RGC axonal growth (Brunet et al., 2005; Yoon et al., 2012). To confirm this, we tested the effects of Vax1 on protein synthesis in RGC axons by quantifying the newly synthesized proteins, measuring the fluorescence intensity of incorporated bioorthogonal noncanonical amino acid azidohomoalanine (AHA), labeled with Alexa Fluor 488 by click chemistry (Dieterich et al., 2007). Treatment with Vax1-His induced a remarkable increase in the fluorescence intensities of AHA-Fluor 488-labeled proteins in RGC axons (Figure 8B, middle column), whereas the Vax1(WF/SR)-His had no effect on protein synthesis (Figure 8B, right column), indicating that intracellular Vax1 stimulated protein synthesis.

In contrast to its significant induction of protein synthesis in axons, Vax1-His-induced effects on AHA-Fluor 488 fluorescence intensities in retinal cell bodies were not notably different from those of Vax1(WF/SR)-His or the 6X-His (Figure 8B, bottom row). Similarly, Vax1 failed to stimulate general translation in the cultured cell-lines and purified polysomes in vitro (data not shown). In contrast, isolated retinal axons from the cell body still responded to Vax 1 as efficiently as those that projected from intact retinal explants (Figure $8 C, D$ ). Taken together, these results suggest that Vax1 stimulates RGC axon growth by stimulating local translation of specific mRNA in the axon rather than by modulating gene expression in the cell body.

\section{Imported Vax1 promotes the access of RGC axons to the midline}

We further investigated whether extracellular Vax1 could restore RGC axon growth towards the midline in $\mathrm{Vax}^{-/-}$mice by re-supplying Vax 1 protein to the $\mathrm{VHT}$ extracellular space. In contrast to the lack of RGC axon access to the vHT observed in Vax $1^{-/-}$mouse embryos, remarkable numbers of RGC axons were detectable in the $\mathrm{vHT}$ of $\mathrm{Vax} 1^{-1-}$ mouse embryos implanted with collagen gels that released recombinant Vax1-His (Figure 9A, top rows of left two columns, B). Remarkable number of RGC axons were able to grow to the source of extracellular Vax1 protein (i.e., the third ventricle), although they failed to restore the OC. In contrast, implantation of collagen gels that released cell-penetration-defective Vax1(WF/SR)-His did not induce the regrowth of RGC axons (Figure 9A, [third column], B). Implanted recombinant Vax1-His was detectable in RGC axons, whereas Vax1(WF/SR)-His was not, suggesting that the implanted Vax1 stimulated RGC axon growth by penetrating into the axoplasm.

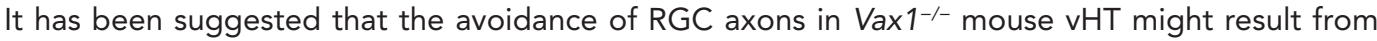
high concentrations of Slit protein in the ventral-lateral diencephalon (Bertuzzi et al., 1999). In support of this, the growth of RGC axons towards Vax $1^{-/-} \mathrm{vHT}$ explants were partly recovered by sequestering extracellular Slit protein using an Fc-fused extracellular fragment of the Slit receptor Robo1 (Robo1-Fc) (Figure 9-figure supplement 1). Thus, we further investigated the roles of Slit in RGC axon avoidance in Vax $1^{-/-}$mouse embryos using Robo1-Fc. The growth of RGC axons into the vHT was partially rescued by implanting a Robo1-Fc-releasing collagen gel into the third ventricle, an effect that was further enhanced by implantation of gels co-releasing Vax1-His and Robo1-Fc (Figure 9A, two right columns, B).

\section{Discussion}

RGC axonal projection to the $\mathrm{OC}$ is often compared to the spinal commissural axonal projection toward the floor plate (FP). Spinal commissural axons are prevented from prematurely entering the 


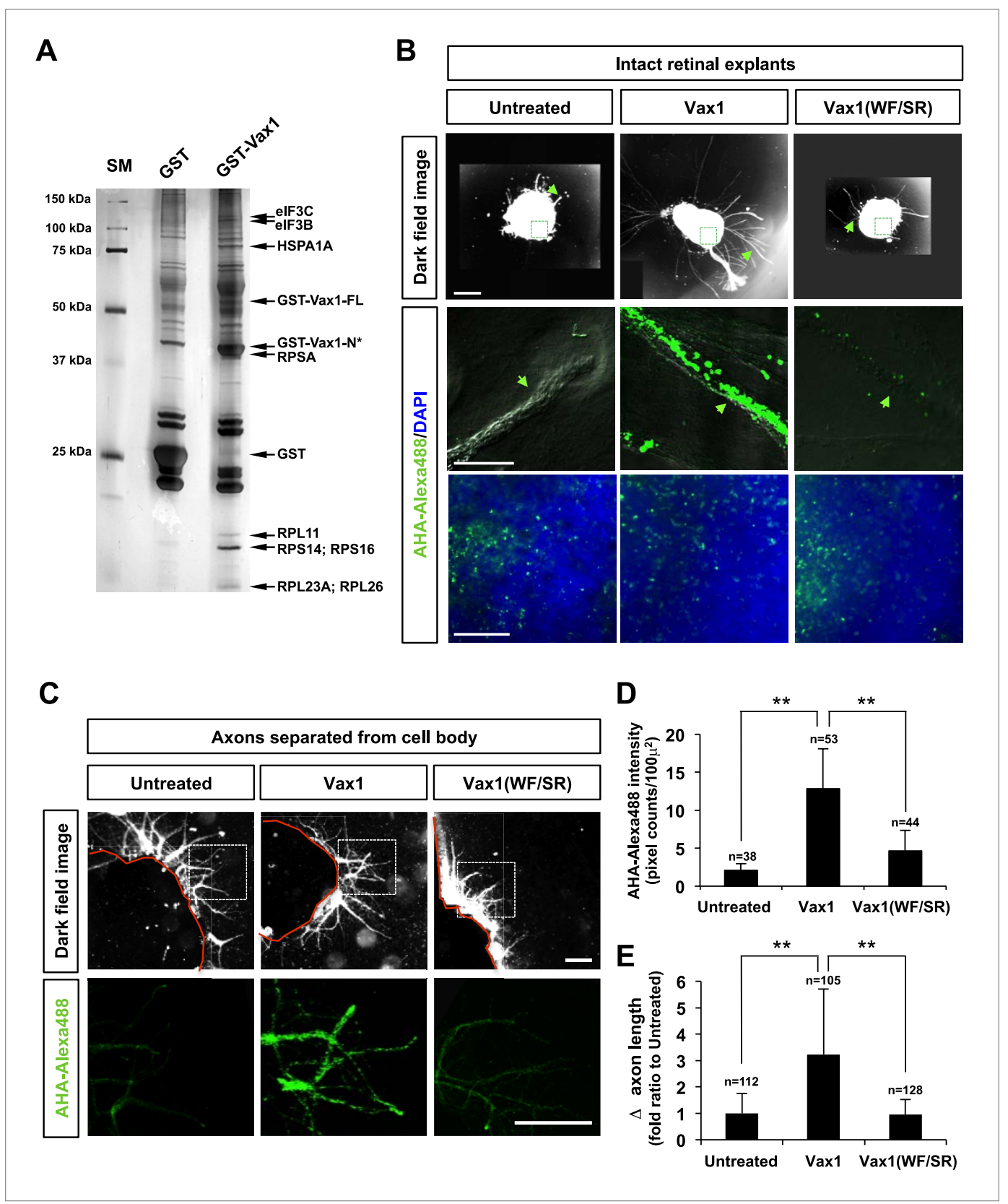

Figure 8. Imported Vax1 induces RGC axonal growth by stimulating local protein synthesis. (A) GST and GST-Vax1 protein complexes were affinity purified from cytoplasmic fractions of HEK293T cells overexpressing GST and GST-Vax1, respectively (see 'Materials and methods' for details). Complexes were then analyzed by SDS-PAGE on $10 \%$ gels and subsequent silver staining to detect proteins specifically enriched in GST-Vax 1 complexes. The identities of protein bands, shown to the right of the gel photograph, were determined by MALDI-TOF mass spectrometry. Vax1-FL, full-length Vax1; Vax1-N*, Vax1 N-terminal fragment. (B) E13.5 mouse retinal explants were cultured for $24 \mathrm{hr}$ before changing to medium containing Vax1-His (100 ng/ml) or Vax1(WF/SR)-His (100 $\mathrm{ng} / \mathrm{ml})$ for an additional $16 \mathrm{hr}$-incubation. The explants were further incubated for $6 \mathrm{hr}$ after addition of the bioorthogonal noncanonical amino acid AHA (L-azidohomoalanine). Newly synthesized proteins incorporating these noncanonical amino acids were labeled with Alexa Fluor 488-alkyne by click chemistry (Dieterich et al., 2007), and the rates of protein synthesis in RGC axons (middle row) and explant cell body (bottom) were assessed by measuring the fluorescence intensities of AHA-Alexa Fluor 488-labeled proteins (see 'Materials and methods' for details). Scale bars: $500 \mu \mathrm{m}$ (top) and $100 \mu \mathrm{m}$ (bottom). (C) The influence of nuclear events in Vax1-induced RGC axon growth was excluded by isolating axons from the cell body before treatment with Vax1 proteins $(100 \mathrm{ng} / \mathrm{ml})$ for $6 \mathrm{hr}$. Arrowheads indicate the area magnified in each inset. Scale bars: $500 \mu \mathrm{m}$. (D) Relative AHA-Alexa488 fluorescence intensities in Figure 8. Continued on next page 
Figure 8. Continued

cell body-free axons were measured using ImageJ software and are shown graphically. Error bars denote SDs. (E) Relative distances that RGC axons grew during this 6-hr incubation period are presented graphically. The values in the graph are averages of fold ratios compared with those of untreated samples. Scores on top of the graph columns in (D) and (E) are number of axons analyzed (** $p<0.001$; ANOVA). Results were obtained from two independent experiments. Numbers of explants analyzed: untreated, $n=4 ; \operatorname{Vax} 1, n=5 ; \operatorname{Vax} 1(W F / S R), n=4$. DOI: 10.7554/eLife.02671.022

The following figure supplement is available for figure 8:

Figure supplement 1. Biophysical properties of Vax1(WF/SR) mutant protein.

DOI: 10.7554/eLife.02671.023

midline by Slit1 expressed in the medial spinal cord and grow in the ventral direction (Stein and Tessier-Lavigne, 2001). In much the same way, Slit1 in the preoptic area and ventral-lateral diencephalon prevents RGC axons from accessing the brain anywhere but at the vHT to form the OC (Erskine et al., 2000; Plump et al., 2002). The spinal commissural axons sense attractive cues, such as netrin and Shh, secreted from the FP (Stein and Tessier-Lavigne, 2001; Charron et al., 2003). The attractive netrin and Shh signals are expected to compete with the co-existing repulsive signal of Slit2, which can be accumulated locally by HSPGs, including $\alpha$-dystroglycan, at the ventral FP (vFP), to determine the directionality of spinal commissural axon growth cones (Matsumoto et al., 2007; Wright et al., 2012). RGC-expressed HSPGs were also reported to play roles as co-receptors for netrin and Slit (Johnson et al., 2004; Hussain et al., 2006; Piper et al., 2006; Ogata-Iwao et al., 2011), suggesting a similar HSPG-based antagonistic regulation of RGC axon growth. However, both netrin and Shh are dispensable with respect to attracting RGC axons toward the vHT and instead function as repulsive cues for RGC axons (Deiner and Sretavan, 1999; Sanchez-Camacho and Bovolenta, 2008). In this study, we propose vHT-secreted Vax1 as a RGC axon growth factor that is analogous to vFP-secreted netrin and Shh. This unconventional axon growth factor also utilizes HSPGs for anchoring to RGC axons (Figure 7) and

A

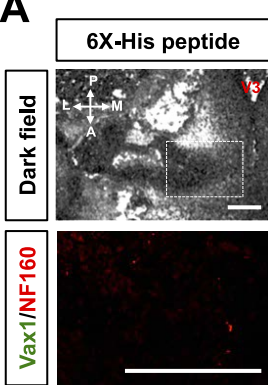

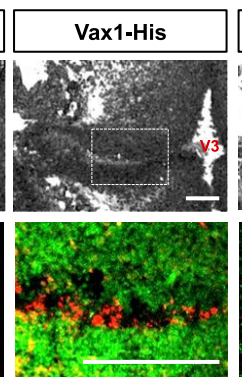

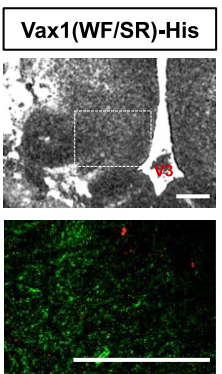

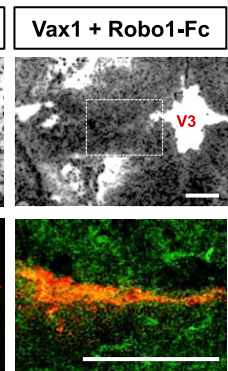

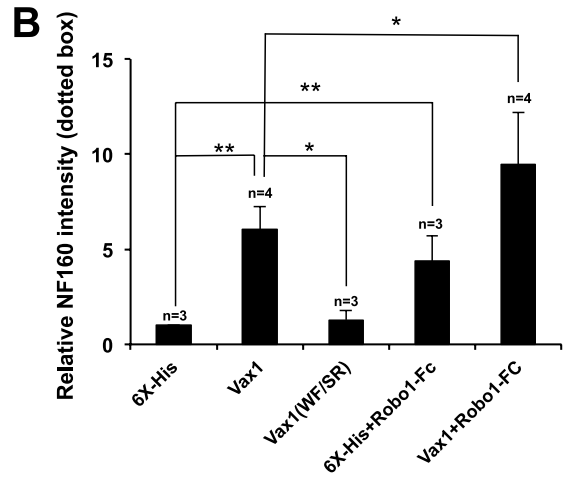

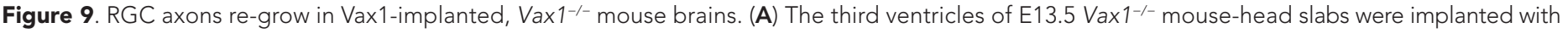
collagen gels mixed with 6 X-His peptide $(4.78 \mu \mathrm{g} / \mathrm{ml} ; 5.69 \mathrm{nmol})$, Vax1-His $(200 \mu \mathrm{g} / \mathrm{ml} ; 5.69 \mathrm{nmol})$, or Vax1(WF/SR)-His (200 $\mu \mathrm{g} / \mathrm{ml} ; 5.69 \mathrm{nmol})$ and incubated for $12 \mathrm{hr}$ (see diagram in Figure 5D and 'Materials and methods' for details). Vax $1^{-1-}$ mouse-head slabs were also implanted with collagen gels mixed with Robo1-Fc fragment ( $1 \mu \mathrm{g} / \mathrm{ml} ; 12.35 \mathrm{pmol}$; R\&D Systems, Minneapolis, MN, USA) in the presence of $6 X-H i s$ peptide $(4.78 \mu \mathrm{g} / \mathrm{ml}$; $5.69 \mathrm{nmol})$ or Vax1-His $(200 \mu \mathrm{g} / \mathrm{ml} ; 5.69 \mathrm{nmol})$ and incubated for $12 \mathrm{hr}$. The fluorescence images of horizontal sections of head slabs were obtained using an Olympus FV1000 confocal microscopy equipped with a transmitted light detector (top row). The same embryonic sections were further stained with rabbit anti-Vax1 (green) and mouse anti-NF160 (red) antibodies (bottom row). (B) Fluorescence intensities of NF160 immunostains in the boxed areas in (A) were measured using ImageJ software and are presented graphically. The values are intensities expressed relative to rb-lgG-treated samples, and error bars denote SDs (**p $<0.001$; ANOVA). Numbers on top of the graph columns are head-slab preparations. DOI: 10.7554 /eLife.02671.024

The following figure supplements are available for figure 9:

Figure supplement 1. vHT-secreted Silt inhibits RGC axon growth. DOI: 10.7554/eLife.02671.025

Figure supplement 2. Reciprocal antagonism between Vax1 and Slit2 in vitro. DOI: 10.7554/eLife.02671.026 
could compete with Slit for HSPGs binding in vitro (Figure 9-figure supplement 2). However, it is unclear whether this competition is valid in physiological conditions because Slit does not inhibit RGC axon growth toward the vHT midline (Erskine et al., 2000; Plump et al., 2002). Moreover, cell penetration-defective Vax1(WF/SR) mutant could not induce RGC axon growth in vivo as well as in vitro, despite of its capability of HSPG binding (Figures 8 and 9, Figure 8-figure supplement 1). It suggests that HSPG binding of Vax 1 is not sufficient to induce RGC axon growth but local protein synthesis induced by internalized Vax 1 is necessary. Collectively, we propose a hypothetical model that Vax1 promotes RGC axon growth towards the $\mathrm{vHT}$ midline by directly targeting mRNA in the axons rather than by serving for a conventional axon guidance molecule that binds specific receptors and triggers on intracellular signaling cascades (Figure 10). Identification of axonal target mRNA awaits future investigations.

Translation-dependent, but transcription-independent, RGC axon guidance by a secreted transcription factor has also been reported for En2, which regulates RGC growth cone turning by increasing the expression of mitochondrial proteins involved in elevating the local ATP, which potentiates ephrin A5 signaling (Brunet et al., 2005; Stettler et al., 2012; Yoon et al., 2012). Since Vax1 and En2 share a homologous homeodomain, Vax 1 could function in a similar manner by cooperating with attractive RGC axon guidance cues, such as VEGF164 and NrCAM (Williams et al., 2006; Erskine et al., 2011; Kuwajima et al., 2012), and by modulating mitochondrial activity. Conversely, En2 could also use HSPGs to bind target axons and fine-tune their selective growth.

In their use of HSPGs as docking sites for RGC axons, Vax1 can be compared to Otx2 that binds specifically to CSPGs of the perineuronal net surrounding parvalbumin (PV) neurons in the visual cortex (Beurdeley et al., 2012; Miyata et al., 2012). The differential affinities of Vax1 and Otx2 for HS and CS might be related to their different homeodomains. Among homeodomain proteins proven to exhibit transfer, Vax1 possesses an antennapedia class homeodomain homologous to that of Emx2 and En2, whereas Otx2 shares a paired class homeodomain similar to that of Pax6 (paired box 6) (Bürglin, 2011;
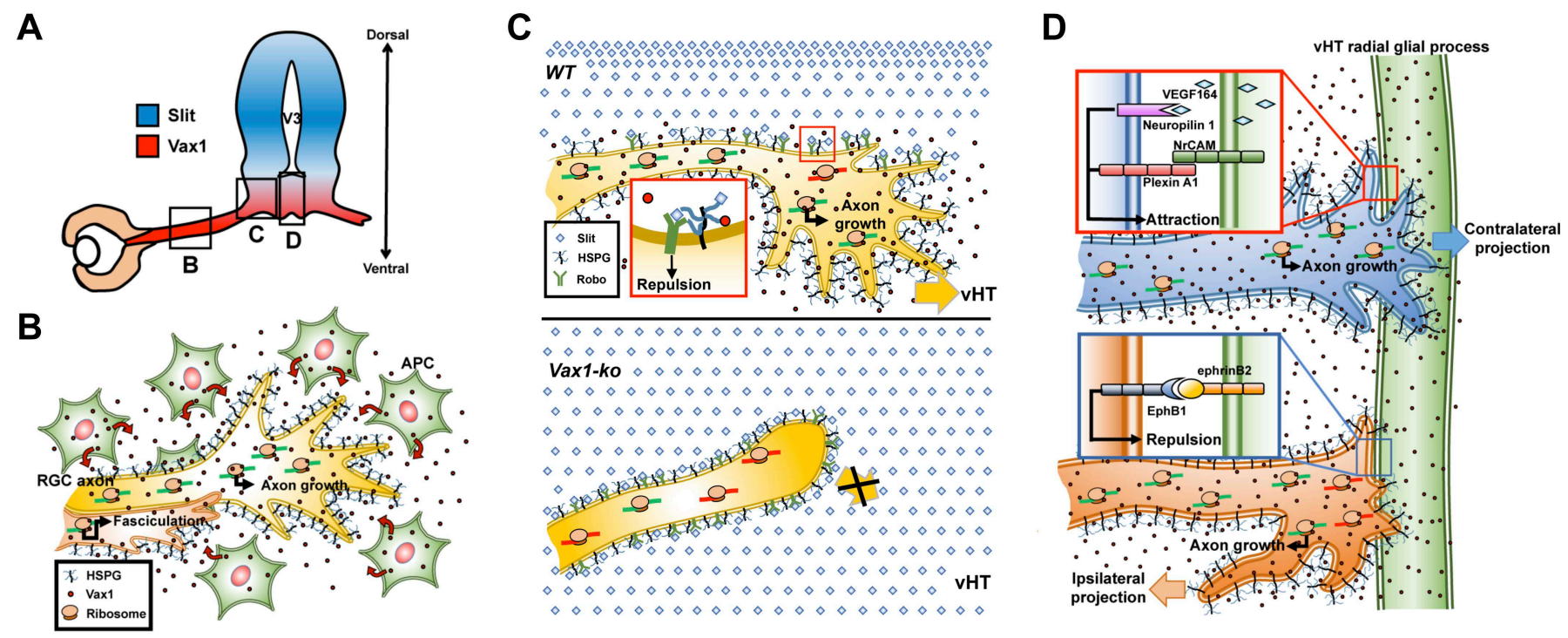

Figure 10. Model depicting Vax1 functions as a secreted retinal axon growth factor. Vax 1 is expressed in radial glia and NPCs of the vHT as well as the OS APCs (A) and secreted to the extracellular space (B). RGC axons that grow in the OS capture APC-secreted Vax1 by HSPGs, resulting in an increase in Vax1 concentration at RGC axons for subsequent penetration and local activation of translation in the axon (B). The imported Vax1 in RGC axoplasm not only promotes axonal growth towards the $\mathrm{vHT}$, but it also enhances fasciculation of RGC axons. This axon growth stimulatory activity of Vax 1 supports sustained RGC axon growth to the vHT midline after the axons were avoided from progressing to dorsal diencephalon, which expresses high concentration of Slit repulsive axon guidance cue (C, top). Therefore, RGC axons stop at the lateral wall of Vax1-ko mouse diencephalon and fail to access the midline (C, bottom). At the VHT midline, RGC axon guidance cues, including VEGF164, NrCAM, and ephrinB2, determine the directionalities of RGC axon growth cones by acting their specific receptors (D). Vax1 does not likely determine the directionalities of RGC axon growth cone at the midline but does promote the growth of the RGC axon shaft as well as the growth cone regardless of their original positions in the retina.

DOI: 10.7554 /eLife.02671.027 
Spatazza et al., 2013). One intriguing possibility that has not yet been explored is that these secreted homeodomain proteins share the property of preferential binding to HS and CS; however, it is at least as likely that intercellular transfer of homeodomain proteins are target-selective events.

Vax2 was not as effectively secreted from COS7 cells as Vax1 (Figure 2), despite sharing an identical homeodomain with Vax1. This suggests that secretion of Vax1 is not solely mediated by the homeodomain but is also dependent on a three-dimensional structure that supports the secretion property of the homeodomain. Unlike Vax1, Vax2 undergoes a specific phosphorylation that results in its cytoplasmic retention (Kim and Lemke, 2006). Phosphorylation of En2 inhibits its secretion (Maizel et al., 2002), suggesting that the phosphorylation might change the structure of these proteins in such a way that it interferes with homeodomain recognition by secretion regulators. However, phosphorylationdefective Vax1(S170A) was still unable to be secreted from COS7 cells (data not shown). Instead, Vax2 could be secreted from different types of cells, where Vax2 might form three-dimensional structures that can be recognizable by secretion machineries (Lee et al., unpublished data). The results suggest that the secretion of homeodomain proteins is a cell context-dependent event.

Multiple midline-crossing defects, including agenesis of the corpus callosum, anterior commissure, and hippocampal commissure, are observed in Vax1-deficient mice and homozygous VAX1 mutant human patients (Bertuzzi et al., 1999; Slavotinek et alo, 2012). However, the molecular functions of Vax 1 in the development of these structures remain unknown. In this study, we show that Vax1induced RGC axonal growth is independent of its transcription factor activity (Figures $2 \mathrm{~A}$ and $3 \mathrm{C}$ ). Instead, Vax1 acts as a regulator of translation after penetrating into RGC axons (Figure 8). Although we cannot rule out Vax1 functions as a transcription factor in the development of those commissures, our results suggest a potential role of secreted Vax1 in the growth of cortical axons (Min et al., unpublished data). Whether axonal growth of these commissural axons in the mammalian forebrain also requires local protein synthesis triggered by Vax 1 protein secreted from cells located in other midline structures, such as the ventral-medial telencephalon and the septum, is a question that warrants further investigation.

\section{Materials and methods}

\section{Mice and explant culture}

Vax1 knock-out $\left(V_{a x} 1^{--}\right)$and Vax1 knock-in (Vax1laczlacz) mice were reported previously (Bertuzzi et al., 1999; Hallonet et al., 1999). Retinal and vHT explants were cultured as described previously (Sato et al., 1994). Briefly, retinal or $\mathrm{vHT}$ explants were added to a collagen mixture and positioned on plates coated with poly-L-lysine $(10 \mu \mathrm{g} / \mathrm{ml})$ and laminin $(10 \mu \mathrm{g} / \mathrm{ml})$. The explants were then incubated at $37^{\circ} \mathrm{C}$ for $1 \mathrm{hr}$ to allow gelling before adding Neurobasal medium containing B27 supplement (Invitrogen, Carlsbad, CA, USA). COS7 cell droplets ( $10^{5}$ cells/droplet) were also prepared using the same procedures. The explants were cultured alone or co-cultured with vHT or COS7 explants for $48 \mathrm{hr}$ before treating with proteins and antibodies.

For time-lapse recording of retinal axon growth, mouse retinal explants were treated with FITClabeled 6 X-His peptide $(100 \mathrm{ng} / \mathrm{ml}, 500 \mathrm{ng} / \mathrm{ml})$ or Vax1-His protein $(500 \mathrm{ng} / \mathrm{ml})$ for $24 \mathrm{hr}$ and photographed every 15 min using a Zeiss Axio Observer Z1 inverted microscope. The explants were washed twice with phosphate-buffered saline (PBS) prior to incubation with rabbit anti-Vax1 polyclonal antibody ( $\alpha$-Vax1; 1:100) for 30 min to detect Vax1-His located on the cell surface. The explants were then washed with PBS and fixed in $4 \%$ paraformaldehyde (PFA)/PBS for subsequent immunostaining procedures to detect total Vax1-His protein inside and outside of cells.

For slab embryo culture with collagen gel implantation, E13.5 mouse embryos were moved onto culture slide chambers containing collagen mixture, positioning the dorsal part on top, after dissecting out the dorsal half of the brain and lower part of the mouth. Droplets of collagen solution mixed with pre-immune IgG $(1 \mu \mathrm{g} / \mathrm{ml})$, $\alpha$-Vax $1(1 \mu \mathrm{g} / \mathrm{ml}), 6 X$-His peptide $(4.78 \mu \mathrm{g} / \mathrm{ml})$, or Vax 1 -His $(200 \mu \mathrm{g} / \mathrm{ml})$ protein were then delivered into the third ventricle of the slab embryos. The embryos were then filled with culture medium and incubated for $12 \mathrm{hr}$ at $37^{\circ} \mathrm{C}$ in a humidified atmosphere supplemented with $7 \% \mathrm{CO}_{2}$. The embryos were fixed in $4 \%$ PFA/PBS for subsequent freezing in OCT (optimal cutting temperature) medium. RGC axon growth at the vHT was monitored along the horizontal axis of slidemounted embryonic brain sections under an Olympus BX-71 microscope. The slides were then stained with appropriate antibodies and examined under an Olympus FV1000 confocal microscope to detect the penetration of implanted Vax1 protein into RGC axons. 


\section{Retinal axon count}

Relative axon counts (combined values of numbers and lengths of axons) of retinal explants were obtained by measuring NF160-fluorescent pixels in images of retinal axons using the ImageJ software. Relative axon counts of retinal explants co-cultured with the vHT explants or COS7 cell aggregates were obtained along three angle segments: forward (+), neutral (0), and reverse (-). A clockwise angle from a line connecting two centers of explants was obtained and classified as forward direction (+) if it was between $0^{\circ}$ and $60^{\circ}$ or between $301^{\circ}$ and $360^{\circ}$; neutral direction (0) if it was between $61^{\circ}$ and $120^{\circ}$ or between $241^{\circ}$ and $300^{\circ}$; and reverse direction (-) if it was between $121^{\circ}$ and $240^{\circ}$ (Figures $2 B$ and $5 B$ ). Relative axon counts in each angle segment were then obtained by comparing the pixel counts of NF160 immunofluorescence in RGC axons of the explants in each angle segment.

\section{Antibodies}

a-Vax1 and $\alpha$-Vax2 were produced as reported previously (Mui et al., 2005). Commercially available antibodies against the following proteins were used: mouse anti-Myc (Santa Cruz Biotechnology, Dallas, TX, USA), mouse anti-GFP (Santa Cruz Biotechnology, Dallas, TX, USA), mouse anti-tubulin $\beta$-III (Tuj1; Covance, Princeton, NJ, USA), goat anti-Sox2 (Santa Cruz Biotechnology, Dallas, TX, USA), mouse anti-Nestin (RC2; Millipore, Billerica, MA, USA), mouse anti- $\beta$-galactosidase (Developmental Studies Hybridoma Bank, DSHB), mouse anti-NF160 (Developmental Studies Hybridoma Bank [DSHB], lowa City, IA, USA), goat anti-Sdc2 (Santa Cruz Biotechnology, Dallas, TX, USA), goat anti-Sdc3 (Santa Cruz Biotechnology (Dallas, TX, USA), for immunohistochemistry), rabbit anti-Sdc3 (Abcam (UK), for Western blot), rabbit anti-Glp1 (Santa Cruz Biotechnology, Dallas, TX, USA), and rabbit anti-Pax2 (Invitrogen, Carlsbad, CA, USA) antibodies.

\section{Immunohistochemistry}

The heads of embryonic mice were fixed in $4 \%$ PFA/PBS at $4^{\circ} \mathrm{C}$ for $2-16 \mathrm{hr}$, depending on the protein to be detected, and then incubated in a $20 \%$ sucrose/PBS solution at $4^{\circ} \mathrm{C}$ for $16 \mathrm{hr}$ before embedding in OCT medium for freezing. Sections of frozen tissue were incubated for $1 \mathrm{hr}$ in a blocking solution containing $0.2 \%$ Triton X-100, $5 \%$ normal donkey serum, and $2 \%$ bovine serum albumen (BSA) in PBS. Sections were first incubated with the indicated primary antibodies in blocking solution without $0.2 \%$ Triton $\mathrm{X}-100$ at $4^{\circ} \mathrm{C}$ for $16 \mathrm{hr}$ and then with the appropriate Alexa488-, Cy3-, or Cy5-conjugated secondary antibody. Immunofluorescence was subsequently analyzed using Olympus FV1000 and Zeiss LSM710 confocal microscopes.

\section{Isolation and detection of extracellular proteins in growth media and CSF}

Growth medium or CSF from the lateral ventricle of E14.5 mice was centrifuged twice at $500 \times g$ for $10 \mathrm{~min}$ and then twice at $2000 \times \mathrm{g}$ for $15 \mathrm{~min}$ to obtain supernatant (S3) fractions. The S3 fractions were then mixed with an equal volume of $3 \mathrm{M}$ trichloroacetic acid (TCA) solution to precipitate the macromolecules. The TCA precipitates were washed twice with $100 \%$ acetone, air-dried pellets, and dissolved in $2 \times$-sodium dodecyl sulfate (SDS) sample buffer for SDS-PAGE (polyacrylamide gel electrophoresis) analysis.

\section{Drosophila lines and whole-mount immunostaining}

Ptc-Gal4, UAS-DsRed, UAS-Sdc, UAS-Dlp, and sdc ${ }^{23}$ flies were obtained from the Bloomington stock center, IN, USA. The UAS-Vax1-EGFP fly was generated by injection of pUAS-Vax1-EGFP constructed by cloning mouse Vax1 cDNA into the pUAST-EGFP vector. Third-instar larvae of PtcGal4>UAS-Vax1-EGFP,UAS-DsRed; + were obtained from a cross of the Ptc-Gal4>UAS-DsRed;TM6B fly with a UAS-Vax1-EGFP fly.

After fixing larval wing imaginal discs with 4\% PFA/PBS for $30 \mathrm{~min}$, the Ptc-Gal4-induced green fluorescence signals from EGFP and Vax1-EGFP proteins were compared with red fluorescence signals from DsRed proteins by confocal microscopy (Olympus FV1000).

\section{Co-immunoprecipitation}

HEK293T cells and E14.5 mouse optic nerves were lysed in a buffer consisting of $10 \mathrm{mM}$ Tris- $\mathrm{HCl}$ $(\mathrm{pH} 7.4), 200 \mathrm{mM} \mathrm{NaCl}, 1 \%$ Triton X-100, and 1\% NP-40. Cell lysates were centrifuged at $12000 \times \mathrm{g}$ for $10 \mathrm{~min}$ at $4^{\circ} \mathrm{C}$. The supernatants were collected and incubated with the indicated antibodies at $4^{\circ} \mathrm{C}$ 
for $16 \mathrm{hr}$; then, protein $\mathrm{A}$-agarose beads were added and incubation was continued at $4^{\circ} \mathrm{C}$ for $1 \mathrm{hr}$. After washing the immune complexes five times with lysis buffer, proteins were eluted with $2 \times$ SDS sample buffer. Samples were then analyzed by SDS-PAGE and Western blotting.

\section{GST-affinity purification of Vax1-interacting proteins}

HEK293T cells transfected with pEBG or pEBG-Vax1 were lysed with a buffer consisting of $10 \mathrm{mM}$ Tris- $\mathrm{HCl}$ (pH 7.4), $200 \mathrm{mM} \mathrm{NaCl}$, and 1\% NP-40. Cell lysates were centrifuged at $12000 \times \mathrm{g}$ for $10 \mathrm{~min}$ at $4^{\circ} \mathrm{C}$. The supernatants were collected and incubated with glutathione Sepharose 4B resin (GE Healthcare) at $4^{\circ} \mathrm{C}$ for $1 \mathrm{hr}$. After washing five times with lysis buffer, proteins were eluted with $2 \times$ SDS sample buffer and samples were analyzed by SDS-PAGE on $10 \%$ gels. Gels were stained using Silver Stain Kit for Mass Spectrometry (Pierce) to isolate bands for MALDI-TOF mass spectrometry analysis at the Korea Basic Science Institute (KBSI), Daejeon, South Korea.

\section{Click chemistry for labeling newly synthesized proteins}

Explant culture media were replaced with methionine-free media, 30 min prior to the addition of $50 \mu \mathrm{M}$ L-azidohomoalanine (AHA, Invitrogen (Carlsbad, CA, USA)). After $6 \mathrm{hr}$, retinal explants were washed twice with PBS containing $1 \%$ fetal bovine serum (FBS) and then $30 \mu \mathrm{M}$ DIBO-Alexa Fluor 488 (Invitrogen, Carlsbad, CA, USA) in PBS containing 1\% FBS was added. The explants were then incubated at room temperature in the dark for $1 \mathrm{hr}$. After washing four times in PBS containing $1 \%$ FBS, retinal explants were fixed with 4\% PFA in PBS for $15 \mathrm{~min}$ at room temperature for subsequent detection of the fluorescence of proteins incorporating AHA-Alexa Fluor 488.

\section{Acknowledgements}

We thank Drs. Greg Lemke, Peter Gruss, and Eok-Soo Oh for providing Vax1-ko mice, Vax1lacz knock-in mice, and GFP-Sdc2 constructs, respectively. We also thank to Dr. Jong Soon Choi for the support with MALDI-TOF mass spectrometry analysis. This work was supported by grants from the Global Research Laboratory Program (NRF-2009-00424; JWK), Brain Research Program (NRF-2013056566; JWK), Basic Science Research Program (NRF-2014R1A2A2A01003069; JWK), and Stem Cell Research Program (NRF-2006-2004289; KHK) funded by the Korean Ministry of Science, ICT, and Future Planning (MSIP). This study was performed in strict accordance with the recommendations in the Guide for the Care and Use of Laboratory Animals of the Korean Ministry of Agriculture, Food, and Rural Affairs. All of the animals were handled according to approved institutional animal care and use committee (IACUC) protocols (\#13-130) of Korea Advanced Institute of Science and Technology.

\section{Additional information}

\begin{tabular}{lll}
$\begin{array}{l}\text { Funding } \\
\text { Funder }\end{array}$ & Grant reference number & Author \\
\hline $\begin{array}{l}\text { Ministry of Science, ICT, and } \\
\text { Future Planning, Republic of }\end{array}$ & NRF-2009-00424; NRF-2013-056566; & Jin Woo Kim \\
Korea & & \\
\hline $\begin{array}{l}\text { Ministry of Science, ICT, and } \\
\text { Future Planning, Republic of } \\
\text { Korea }\end{array}$ & NRF-2006-2004289 & Kyung Hwa Kang \\
\hline
\end{tabular}

The funder had no role in study design, data collection and interpretation, or the decision to submit the work for publication.

Author contributions

NK, KWM, Acquisition of data, Analysis and interpretation of data, Drafting or revising the article, Contributed unpublished essential data or reagents; KHK, EJL, Acquisition of data, Analysis and interpretation of data, Contributed unpublished essential data or reagents; H-TK, KM, DL, S-HL, Acquisition of data, Analysis and interpretation of data; JC, Analysis and interpretation of data, Drafting or revising the article; JWK, Conception and design, Analysis and interpretation of data, Drafting or revising the article 
Ethics

Animal experimentation: This study was performed in strict accordance with the recommendations in the Guide for the Care and Use of Laboratory Animals of the Korean Ministry of Agriculture, Food and Rural Affairs. All of the animals were handled according to approved institutional animal care and use committee (IACUC) protocols (\#13-130) of Korea Advanced Institute of Science and Technology.

\section{References}

Barbieri AM, Lupo G, Bulfone A, Andreazzoli M, Mariani M, Fougerousse F, Consalez GG, Borsani G, Beckmann JS, Barsacchi G, Ballabio A, Banfi S. 1999. A homeobox gene, vax2, controls the patterning of the eye dorsoventral axis. Proceedings of the National Academy of Sciences of USA 96:10729-10734. doi: 10.1073/pnas.96.19.10729.

Bertuzzi S, Hindges R, Mui SH, O'Leary DD, Lemke G. 1999. The homeodomain protein vax1 is required for axon guidance and major tract formation in the developing forebrain. Genes \& Development 13:3092-3105. doi: $10.1101 /$ gad.13.23.3092.

Beurdeley M, Spatazza J, Lee HH, Sugiyama S, Bernard C, Di Nardo AA, Hensch TK, Prochiantz A. 2012. Otx2 binding to perineuronal nets persistently regulates plasticity in the mature visual cortex. The Journal of Neuroscience 32:9429-9437. doi: 10.1523/JNEUROSCI.0394-12.2012.

Bishop JR, Schuksz M, Esko JD. 2007. Heparan sulphate proteoglycans fine-tune mammalian physiology. Nature 446:1030-1037. doi: 10.1038/nature05817.

Brunet I, Weinl C, Piper M, Trembleau A, Volovitch M, Harris W, Prochiantz A, Holt C. 2005. The transcription factor Engrailed-2 guides retinal axons. Nature 438:94-98. doi: 10.1038/nature04110.

Bürglin TR. 2011. Homeodomain subtypes and functional diversity. A handbook of transcription factors. p. 95-122.

Charron F, Stein E, Jeong J, McMahon AP, Tessier-Lavigne M. 2003. The morphogen sonic hedgehog is an axonal chemoattractant that collaborates with netrin-1 in midline axon guidance. Cell 113:11-23. doi: 10.1016/ S0092-8674(03)00199-5.

Chung KY, Leung KM, Lin L, Chan SO. 2001. Heparan sulfate proteoglycan expression in the optic chiasm of mouse embryos. The Journal of Comparative Neurology 436:236-247. doi: 10.1002/cne.1245.

Deiner MS, Sretavan DW. 1999. Altered midline axon pathways and ectopic neurons in the developing hypothalamus of netrin-1- and DCC-deficient mice. The Journal of Neuroscience 19:9900-9912.

Dieterich DC, Lee JJ, Link AJ, Graumann J, Tirrell DA, Schuman EM. 2007. Labeling, detection and identification of newly synthesized proteomes with bioorthogonal non-canonical amino-acid tagging. Nature Protocols 2:532-540. doi: 10.1038/nprot.2007.52.

Erskine L, Herrera E. 2007. The retinal ganglion cell axon's journey: insights into molecular mechanisms of axon guidance. Developmental Biology 308:1-14. doi: 10.1016/j.ydbio.2007.05.013.

Erskine L, Reijntjes S, Pratt T, Denti L, Schwarz Q, Vieira JM, Alakakone B, Shewan D, Ruhrberg C. 2011. VEGF signaling through neuropilin 1 guides commissural axon crossing at the optic chiasm. Neuron 70:951-965. doi: 10.1016/j.neuron.2011.02.052.

Erskine L, Williams SE, Brose K, Kidd T, Rachel RA, Goodman CS, Tessier-Lavigne M, Mason CA. 2000. Retinal ganglion cell axon guidance in the mouse optic chiasm: expression and function of robos and slits. The Journal of Neuroscience 20:4975-4982.

Hallonet M, Hollemann T, Pieler T, Gruss P. 1999. Vax1, a novel homeobox-containing gene, directs development of the basal forebrain and visual system. Genes \& Development 13:3106-3114. doi: 10.1101/ gad.13.23.3106.

Hallonet M, Hollemann T, Wehr R, Jenkins NA, Copeland NG, Pieler T, Gruss P. 1998. Vax1 is a novel homeoboxcontaining gene expressed in the developing anterior ventral forebrain. Development 125:2599-2610.

Hussain SA, Piper M, Fukuhara N, Strochlic L, Cho G, Howitt JA, Ahmed Y, Powell AK, Turnbull JE, Holt CE, Hohenester E. 2006. A molecular mechanism for the heparan sulfate dependence of slit-robo signaling. The Journal of Biological Chemistry 281:39693-39698. doi: 10.1074/jbc.M609384200.

Inatani M, Irie F, Plump AS, Tessier-Lavigne M, Yamaguchi Y. 2003. Mammalian brain morphogenesis and midline axon guidance require heparan sulfate. Science 302:1044-1046. doi: 10.1126/science.1090497.

Johnson KG, Ghose A, Epstein E, Lincecum J, O'Connor MB, Van Vactor D. 2004. Axonal heparan sulfate proteoglycans regulate the distribution and efficiency of the repellent slit during midline axon guidance. Current Biology 14:499-504. doi: 10.1016/j.cub.2004.02.005.

Joliot A, Maizel A, Rosenberg D, Trembleau A, Dupas S, Volovitch M, Prochiantz A. 1998. Identification of a signal sequence necessary for the unconventional secretion of Engrailed homeoprotein. Current Biology 8:856-863. doi: 10.1016/S0960-9822(07)00346-6.

Joliot A, Prochiantz A. 2004. Transduction peptides: from technology to physiology. Nature Cell Biology 6:189-196. doi: 10.1038/ncb0304-189.

Kim JW, Lemke G. 2006. Hedgehog-regulated localization of Vax2 controls eye development. Genes \& Development 20:2833-2847. doi: 10.1101/gad.1462706.

Kuwajima T, Yoshida Y, Takegahara N, Petros TJ, Kumanogoh A, Jessell TM, Sakurai T, Mason C. 2012. Optic chiasm presentation of Semaphorin6D in the context of Plexin-A1 and Nr-CAM promotes retinal axon midline crossing. Neuron 74:676-690. doi: 10.1016/j.neuron.2012.03.025. 
Lee JS, Chien CB. 2004. When sugars guide axons: insights from heparan sulphate proteoglycan mutants. Nature Reviews Genetics 5:923-935. doi: 10.1038/nrg1490.

Lemke G, Reber M. 2005. Retinotectal mapping: new insights from molecular genetics. Annual Review of Cell and Developmental Biology 21:551-580. doi: 10.1146/annurev.cellbio.20.022403.093702.

Maizel A, Tassetto M, Filhol O, Cochet C, Prochiantz A, Joliot A. 2002. Engrailed homeoprotein secretion is a regulated process. Development 129:3545-3553.

Matsumoto Y, Irie F, Inatani M, Tessier-Lavigne M, Yamaguchi Y. 2007. Netrin-1/DCC signaling in commissural axon guidance requires cell-autonomous expression of heparan sulfate. The Journal of Neuroscience 27:4342-4350. doi: 10.1523/JNEUROSCI.0700-07.2007.

Miyata S, Komatsu Y, Yoshimura Y, Taya C, Kitagawa H. 2012. Persistent cortical plasticity by upregulation of chondroitin 6-sulfation. Nature Neuroscience 15:414-422, S411-S412. doi: 10.1038/nn.3023.

Mui SH, Kim JW, Lemke G, Bertuzzi S. 2005. Vax genes ventralize the embryonic eye. Genes \& Development 19:1249-1259. doi: 10.1101/gad.1276605.

Nakagawa S, Brennan C, Johnson KG, Shewan D, Harris WA, Holt CE. 2000. Ephrin-B regulates the Ipsilateral routing of retinal axons at the optic chiasm. Neuron 25:599-610. doi: 10.1016/ S0896-6273(00)81063-6.

Ogata-Iwao M, Inatani M, Iwao K, Takihara Y, Nakaishi-Fukuchi Y, Irie F, Sato S, Furukawa T, Yamaguchi Y, Tanihara H. 2011. Heparan sulfate regulates intraretinal axon pathfinding by retinal ganglion cells. Investigative Ophthalmology \& Visual Science 52:6671-6679. doi: 10.1167/iovs.11-7559.

Petros TJ, Rebsam A, Mason CA. 2008. Retinal axon growth at the optic chiasm: to cross or not to cross. Annual Review of Neuroscience 31:295-315. doi: 10.1146/annurev.neuro.31.060407.125609.

Piper M, Anderson R, Dwivedy A, Weinl C, van Horck F, Leung KM, Cogill E, Holt C. 2006. Signaling mechanisms underlying Slit2-induced collapse of Xenopus retinal growth cones. Neuron 49:215-228. doi: 10.1016/j.neuron.2005.12.008.

Plump AS, Erskine L, Sabatier C, Brose K, Epstein CJ, Goodman CS, Mason CA, Tessier-Lavigne M. 2002. Slit1 and Slit2 cooperate to prevent premature midline crossing of retinal axons in the mouse visual system. Neuron 33:219-232. doi: 10.1016/S0896-6273(01)00586-4.

Pratt T, Conway CD, Tian NM, Price DJ, Mason JO. 2006. Heparan sulphation patterns generated by specific heparan sulfotransferase enzymes direct distinct aspects of retinal axon guidance at the optic chiasm. The Journal of Neuroscience 26:6911-6923. doi: 10.1523/JNEUROSCI.0505-06.2006.

Sanchez-Camacho C, Bovolenta P. 2008. Autonomous and non-autonomous Shh signalling mediate the in vivo growth and guidance of mouse retinal ganglion cell axons. Development 135:3531-3541. doi: 10.1242/dev.023663.

Sato M, Lopez-Mascaraque L, Heffner CD, O'Leary DD. 1994. Action of a diffusible target-derived chemoattractant on cortical axon branch induction and directed growth. Neuron 13:791-803. doi: 10.1016/0896-6273(94)90246-1.

Slavotinek AM, Chao R, Vacik T, Yahyavi M, Abouzeid H, Bardakjian T, Schneider A, Shaw G, Sherr EH, Lemke G, Youssef M, Schorderet DF. 2012. VAX1 mutation associated with microphthalmia, corpus callosum agenesis, and orofacial clefting: the first description of a VAX1 phenotype in humans. Human Mutation 33:364-368. doi: 10.1002/humu.21658.

Soker S, Fidder H, Neufeld G, Klagsbrun M. 1996. Characterization of novel vascular endothelial growth factor (VEGF) receptors on tumor cells that bind VEGF165 via its exon 7-encoded domain. The Journal of Biological Chemistry 271:5761-5767. doi: 10.1074/jbc.271.10.5761.

Spatazza J, Di Lullo E, Joliot A, Dupont E, Moya KL, Prochiantz A. 2013. Homeoprotein signaling in development, health, and disease: a shaking of dogmas offers challenges and promises from bench to bed. Pharmacological Reviews 65:90-104. doi: 10.1124/pr.112.006577.

Spring J, Paine-Saunders SE, Hynes RO, Bernfield M. 1994. Drosophila syndecan: conservation of a cellsurface heparan sulfate proteoglycan. Proceedings of the National Academy of Sciences of USA 91:3334-3338. doi: 10.1073/pnas.91.8.3334.

Stein E, Tessier-Lavigne M. 2001. Hierarchical organization of guidance receptors: silencing of netrin attraction by slit through a Robo/DCC receptor complex. Science 291:1928-1938. doi: 10.1126/science.1058445.

Stettler O, Joshi RL, Wizenmann A, Reingruber J, Holcman D, Bouillot C, Castagner F, Prochiantz A, Moya KL. 2012. Engrailed homeoprotein recruits the adenosine $A 1$ receptor to potentiate ephrin $A 5$ function in retinal growth cones. Development 139:215-224. doi: 10.1242/dev.063875.

Sugiyama S, Di Nardo AA, Aizawa S, Matsuo I, Volovitch M, Prochiantz A, Hensch TK. 2008. Experience-dependent transfer of Otx2 homeoprotein into the visual cortex activates postnatal plasticity. Cell 134:508-520. doi: 10.1016/j. cell.2008.05.054.

Vacik T, Stubbs JL, Lemke G. 2011. A novel mechanism for the transcriptional regulation of Wnt signaling in development. Genes \& Development 25:1783-1795. doi: 10.1101/gad.17227011.

Williams SE, Grumet M, Colman DR, Henkemeyer M, Mason CA, Sakurai T. 2006. A role for Nr-CAM in the patterning of binocular visual pathways. Neuron 50:535-547. doi: 10.1016/j.neuron.2006.03.037.

Williams SE, Mann F, Erskine L, Sakurai T, Wei S, Rossi DJ, Gale NW, Holt CE, Mason CA, Henkemeyer M. 2003. Ephrin-B2 and EphB1 mediate retinal axon divergence at the optic chiasm. Neuron 39:919-935. doi: 10.1016/j. neuron.2003.08.017.

Wright KM, Lyon KA, Leung H, Leahy DJ, Ma L, Ginty DD. 2012. Dystroglycan organizes axon guidance cue localization and axonal pathfinding. Neuron 76:931-944. doi: 10.1016/j.neuron.2012.10.009.

Yoon BC, Jung H, Dwivedy A, O'Hare CM, Zivraj KH, Holt CE. 2012. Local translation of extranuclear lamin B promotes axon maintenance. Cell 148:752-764. doi: 10.1016/j.cell.2011.11.064. 